Guy Finny

\title{
Improving Regional Fisheries Management Organisation Decision-Making: New Hope in the South Pacific?
}

Laws 528: Law of the Sea

Submitted for the LLB (Honours) Degree

Faculty of Law

Victoria University of Wellington

2014 


\begin{abstract}
Regional Fisheries Management Organisations (RFMOs) play a key role in promoting the sustainable management of high seas fisheries. However, many RFMOs are not succeeding in this task. Whilst overexploited fish stocks can be blamed on illegal fishing and on States reluctant to implement robust conservation and management decisions, fault can also be found in the design of RFMO decision-making processes, specifically the use of consensus-based decision-making and objection procedures. This paper evaluates whether a new RFMO, the South Pacific Regional Fisheries Management Organisation, and its 'cutting edge' decision-making procedure, can act as a model for more effective RFMO decision-making.
\end{abstract}




\section{Contents}

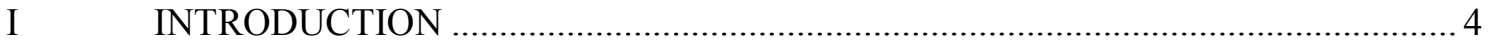

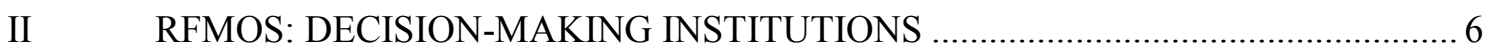

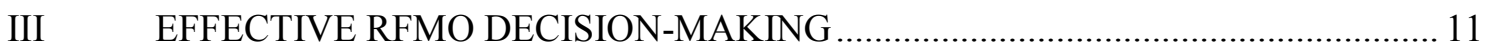

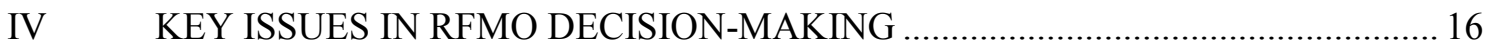

A Decision-Making Based on Consensus and Unanimity ............................................ 17

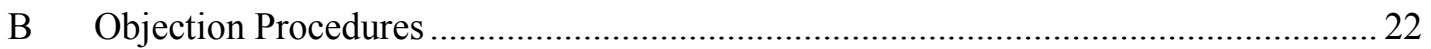

V REFORMING RFMO DECISION-MAKING: SUGGESTED BEST PRACTICE .... 26

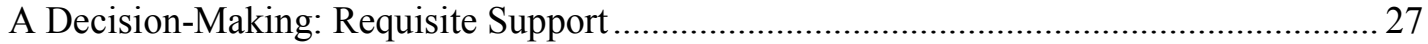

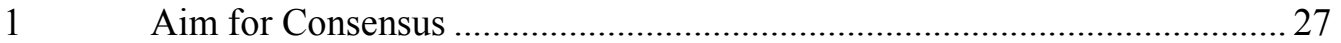

2 Consensus Should be Supported by Majority Voting.................................... 28

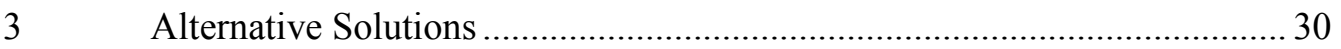

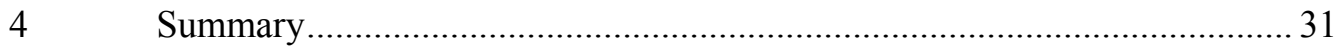

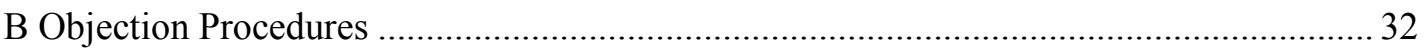

$1 \quad$ The Middle Ground Approach: ................................................................ 32

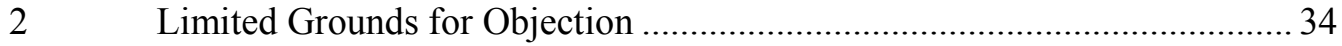

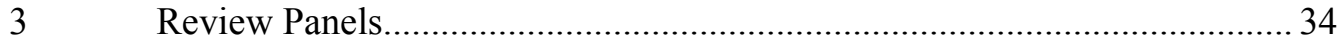

$4 \quad$ Interim and Alternative Measures: .............................................................. 35

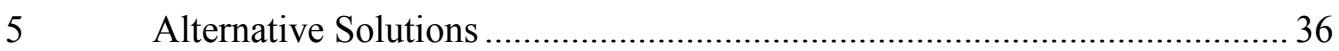

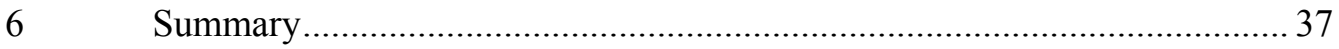

VI SPRFMO: A MODEL FOR RFMO DECISION-MAKING? .................................. 38

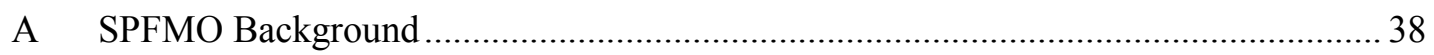

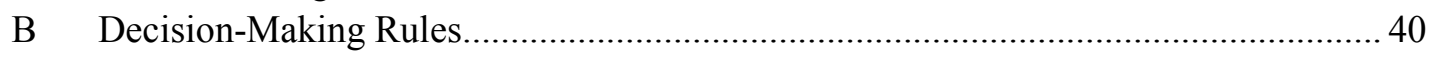

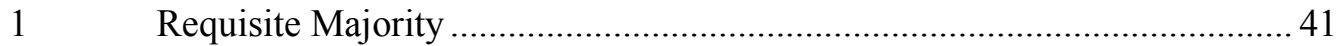

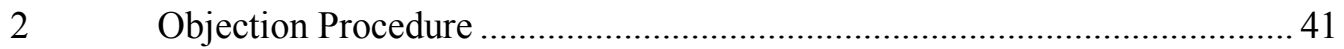

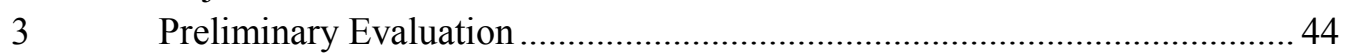

C Case Study: SPRFMO in Light of the Russia Objection ......................................... 47

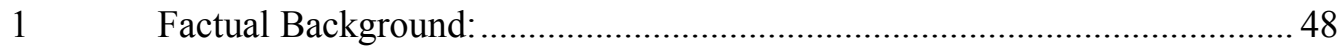

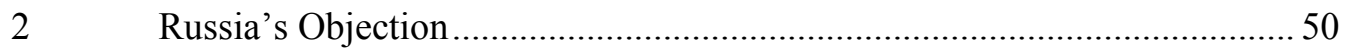

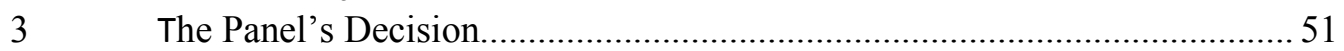

$5 \quad$ Evaluation of SPRFMO in Light of the Russia Dispute ...............................52

D Synthesis: Is SPRFMO a Model for RFMO Decision-Making?.................................. 55

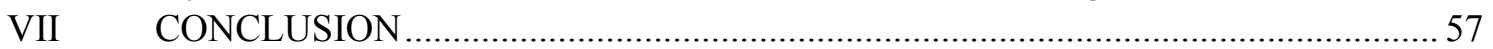

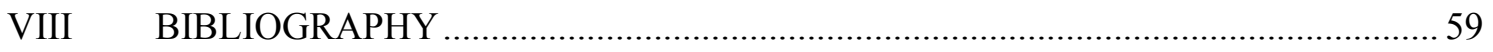

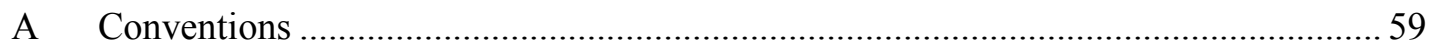

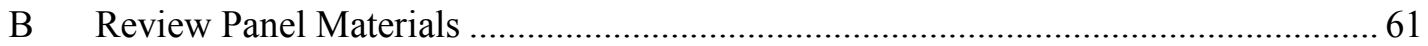

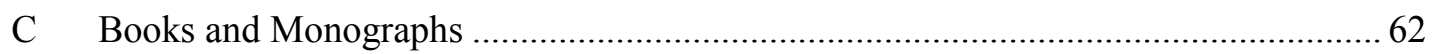

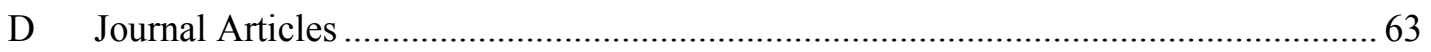

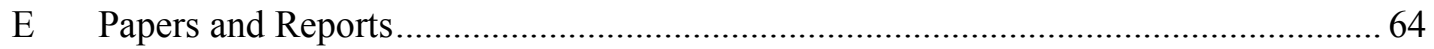

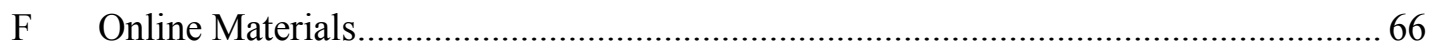




\section{Introduction}

High seas fish stocks are under considerable threat. ${ }^{1}$ There are many factors behind fish stock decline in this maritime zone. Pollution, excess capacity in global fishing fleets, subsidies, climate change and illegal, unregulated and unlawful (IUU) fishing have all been implicated as threats. ${ }^{2}$ Since the late nineteenth century, there have been a multitude of responses in the law of sea to these issues. ${ }^{3}$ One of the most important responses in areas beyond national jurisdiction are regional fisheries management organisations (RFMOs). ${ }^{4}$

RFMOs are defined by the Food and Agriculture Organisation of the United Nations (FAO) as "intergovernmental organisations or arrangements, as appropriate, that have the competence to establish fisheries conservation and management measures". ${ }^{5}$ This ability to develop legally binding conservation measures means RFMOs have a key role in promoting fish stock sustainability and conservation. ${ }^{6}$ The problem with RFMOs is that they have thus far been largely unsuccessful in achieving their objectives of fisheries sustainability. ${ }^{7}$ An estimated two-thirds of straddling and high seas stocks as well as one third of highly migratory tuna species are overexploited or depleted. ${ }^{8}$

On one hand, several of the contributing factors towards fish stock decline are beyond the control of RFMOs, the lack of political will amongst States to implement and enforce

${ }_{1}$ Global Ocean Commission Improving Accountability and Performance in International Fisheries Management (Global Ocean Commission, November 2013) at 1.

2 Secretary-General of the United Nations Oceans and Law of the Sea: Report of the Secretary General $\mathrm{A} / 69 / 71$ (2014) at 3 and 16-17.

${ }^{3}$ Patricia Birnie, Alan Boyle and Catherine Redgwell International Law \& the Environment (Oxford University Press, Oxford, 2009) at 706-709.

${ }^{4}$ See Daniela Diz Pereira Pinto Fisheries Management in Areas Beyond National Jurisdiction: The Impact of Ecosystem Based Law-making (Martinus Nijhoff Publishers, Leiden, 2012) at 117.

${ }^{5}$ Fisheries and Aquaculture Department of the Food and Agriculture Organization of the United Nations [FAO] International Plan of Action to Prevent, Deter and Eliminate Illegal, Unreported and Unregulated Fishing (FAO, 2001) at 3.

${ }^{6}$ Elise Anne Clark "Strengthening Regional Fisheries Management - An Analysis of the Duty to Cooperate" (2011) 9 NZJPIL 223 at 224.

${ }^{7}$ See Sarika Cullis-Suzuki and Daniel Pauly "Failing the High Seas: A Global Evaluation of Regional Fisheries Management Organisations" (2010) 34 Marine Policy 1036.

${ }^{8}$ Jorge Csirke, Serge Garcia, Richard Grainger, Jean-Jacques Maguire and Michael Sissenwine The State of World Highly Migratory, Straddling and Other High Seas Fishery Resources and Associated Species (FAO, Fisheries Technical Paper No 496, 2006). 
robust conservation measures in particular. ${ }^{9}$ On the other, the design of many RFMOs is arguably blunting their efforts to effectively manage fish stocks. ${ }^{10}$ One aspect in particular that is impeding the work of RFMOs are the processes these organisations use to adopt fisheries conservation and management measures. ${ }^{11}$ Specifically, their work has been undermined by requirements for consensus-based decision-making as well as provisions that allow member states to easily opt-out of measures they find unpalatable. ${ }^{12}$

Regardless of the lacklustre performance of RFMOs in the past, they still form "the backbone of high seas fisheries management". ${ }^{13}$ Although, if they are to be truly successful in their task, the principles and processes of many RFMOs will have to undergo significant reform. ${ }^{14}$ It is timely, therefore, that a new RFMO has recently come into force: the South Pacific Regional Fisheries Management Organisation (SPRFMO). ${ }^{15}$ SPRFMO incorporates modern principles and a cutting edge decision-making process. ${ }^{16}$ Combined, these arguably represent best practice for contemporary RFMO decision-making.

The focus of this paper will be on SPRFMO's decision-making process. Before evaluating this decision-making process, and the promise it holds for other RFMOs, this paper will first provide an overview of the context and purpose of RFMOs. It will then explore the issues hampering the effectiveness of RFMO decision-making. This will focus on the

${ }^{9}$ David Anderson, Michael W. Lodge, Terje Løbach, Gordon Munro, Keith Sainsbury, Anna Willock Recommended Best Practices for Regional Fisheries Management Organizations: Report of an Independent Panel to Develop a Model for Improved Governance by Regional Fisheries Management Organisations (Chatham House, 2007) at 134.

${ }^{10}$ FAO Fisheries and Aquaculture Department State of World Fisheries and Aquaculture 2008 (FAO, 2009) at 69 .

${ }^{11}$ Robin Warner Protecting the Oceans Beyond National Jurisdiction: Strengthening the International Legal Framework (Martinus Nijhoff Publishers, Leiden, 2009) at 125-126.

${ }^{12}$ Global Ocean Commission, above $\mathrm{n} 1$, at 5.

${ }^{13}$ At 1 .

${ }^{14}$ See FAO Food and Agriculture Department State of World Fisheries, above n 10, at 69; Robin Warner, above n 11, at 125-126; and Evelyne Meltzer The Quest for Sustainable International Fisheries: Regional Efforts to Implement the 1995 United Nations Fish Stocks Agreement (National Research Council of Canada, 2009) at [4.7].

${ }^{15}$ Convention on the Conservation and Management of High Seas Fishery Resources in the South Pacific Ocean (SPRFMO Convention) [2012] ATS 28 (opened for signature 1 February 2010, entered into force 24 August 2012).

${ }^{16}$ Bill Mansfield "Presentation by the Chairperson of the SPRFMO Commission to the Review Panel" (SPRFMO, July 2013); and Howard S. Schiffman "The South Pacific Regional Fisheries Management Organization (SPRFMO): an improved model of decision-making for fisheries conservation?" (2013) $3 \mathrm{~J}$ Environ Stu Sci 209. 
processes component of RFMO decision-making, rather than the substantive criteria for making decisions. The paper will also develop a framework for best practice RFMO decision-making.

The 'best practice' framework will be used to evaluate whether SPRFMO represents a model for effective RFMO decision-making. A recent case study will then be examined to assess how SPRFMO's approach operates in practice. This will give further insight into whether it can indeed act as a potential model for future RFMO decision-making processes. The paper will conclude that, whilst SPRFMO's decision-making processes will not work for all RFMOs, it is a significant step forward for RFMO decision-making that will hopefully be an impetus for change amongst other such organisations.

\section{RFMOs: Decision-Making Institutions}

There are many problems confronting RFMO decision-making, and this paper contends SPRFMO is part of the solution. However, it is important to first establish the role of RFMOs in the law the sea, and why decision-making is critical to their work. This will provide important context to the issues plaguing RFMO decision-making processes, and potential solutions to these problems.

Fishing has been a long standing freedom of the high seas. ${ }^{17}$ This is the 60 per cent of the world's oceans not included in either territorial seas or exclusive economic zones. ${ }^{18}$ Since the mid-nineteenth century it has been recognised that fisheries are exhaustible, particularly in the face of more efficient technologies and increased fishing capacity. ${ }^{19}$ Additionally, as fisheries within national jurisdictions have been depleted, high seas fisheries have been subject to increasing exploitation. ${ }^{20}$

The lack of a central governing authority in areas beyond national jurisdiction means fish stocks in this zone are especially susceptible to the problem of the tragedy of the commons. ${ }^{21}$ This is the idea "when a resource is held jointly, it is an individual's selfinterest to deplete it, so people will tend to undermine their collective long-term interests

\footnotetext{
${ }^{17}$ Are K. Sydnes "Regional Fishery Organizations: How and Why Organizational Diversity Matters" (2001) 32 Ocean Dev \& Intl'1 L 349 at 351.

${ }^{18}$ Cullis-Suzuki and Pauly "Failing the High Seas", above n 7, at 1036.

${ }^{19}$ Donald R Rothwell and Tim Stephens The International Law of the Sea (Hart Publishing, Portland, 2010) at 292-293.

${ }^{20}$ At 303.

${ }^{21}$ Sydnes, above n 17, at 350-351.
} 
by over-exploiting rather than protecting that asset". ${ }^{22}$ This context means it is imperative that States co-operate in exploiting commercial fisheries.

In responding to the need to co-operate if fish stocks are to be sustainably exploited, the law of the sea has put RFMOs at the heart of addressing the issue of high seas fisheries conservation and management. ${ }^{23}$ Indeed, the need for co-operative regulatory and institutional arrangements to manage these fisheries has prompted the rise of RFMOs. ${ }^{24}$ This was first signalled at the 1958 United Nations Conference on the Law of the Sea, which "agreed for the first time that the conservation and management of high seas fisheries resources could be carried out only through international cooperation in research and regulation". ${ }^{25}$

The principle of international law that States have a duty to cooperate when exploiting living resources on the high seas is now found in international custom, and is articulated in Article 117 of the United Nations Convention on the Law of the Sea (UNCLOS). ${ }^{26}$ Article 117 establishes that all States have "the duty to take, or to cooperate with other States in taking, such measures for their respective nationals as may be necessary for the conservation of the living resources of the high seas". ${ }^{27}$ Moreover, Article 118 also obliges states to: ${ }^{28}$

cooperate with each other in the conservation and management of living resources in the areas of the high seas. States whose nationals exploit identical living resources, or different living resources in the same area, shall enter into negotiations with a view to taking the measures necessary for the conservation of the living resources concerned. They shall, as appropriate, cooperate to establish subregional or regional fisheries organizations to this end.

\footnotetext{
${ }^{22}$ The Economist "Governing the Oceans: The Tragedy of the High Seas" (2014) 410 The Economist 10 at 10 .

${ }^{23}$ Michael Lodge Report and Documentation of the International Workshop on Factors Contributing to Unsustainability and Overexploitation of Fisheries (FAO, Fisheries Report No. 672, 2002) at 104-105

${ }^{24}$ Clark, above 6, at 224-225.

${ }^{25}$ Anderson et al., above $\mathrm{n} 9$, at 2 .

${ }^{26}$ Anderson et al., above $\mathrm{n} 9$, at 70-71.

${ }^{27}$ United Nations Convention on the Law of the Sea [UNCLOS] 1833 UNTS 3 (opened for signature 10 December 1982, entered into force 16 November 1994), art 117.

${ }^{28}$ UNCLOS, art 118.
} 
The key role of RFMOs is to act as an institutional vehicle for this obligation of cooperation. ${ }^{29}$ They do this by facilitating decisions on how the fisheries in their respective areas of competence are to be conserved and managed. Established by treaties, RFMOs "adopt measures on an ongoing basis that they deem necessary or desirable for those conservation and management purposes mandated by the[ir] treaty". ${ }^{30}$

RFMO decisions are typically made through a commission or council composed of representatives of its member States. ${ }^{31}$ Every member of the RFMO has a vote in this decision-making body. Decision are either made "by a majority, a supermajority, or a

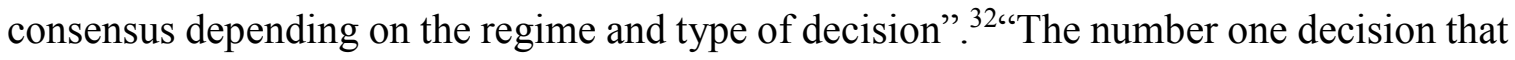
an RFMO needs to make is determining the total allowable catch (TAC) of a given species in a given season." 33

The establishment of a TAC is only one of many decisions the RFMO's Commission will be tasked with making. The RFMO also needs to conduct the politically fraught task of allocating the TAC between its member states in national quotas. ${ }^{34}$ RFMO's also typically make a number of other conservation and management measures including the length of the season, the type of gear that may be used, measures to reduce by-catch, and on whether areas should be closed for fishing. ${ }^{35}$

All RFMO decisions, especially "the determination of the TAC and allocation of the national quotas", are informed by principles. ${ }^{36}$ These include the principle that decisions are to be informed by science, the application of precautionary principle and ecosystem approach, the need for compatibility of decisions between jurisdictions, the principle of non-discrimination between states, and the need to take into account the special

\footnotetext{
${ }^{29}$ Birnie et al., above n 3, at 392-393 and 739; and Anderson et al., above n 9, at 1.

${ }^{30}$ Howard S. Schiffman Marine Conservation Agreements: The Law and Policy of Reservations and Vetoes (Martinus Nijhoff Publishers, Leiden, 2008) at 3.

${ }^{31}$ See Meltzer, above n 14, at [8.4.1].

${ }^{32}$ Howard S. Schiffman "The Evolution of Fisheries Conservation and Management: A Look at the New South Pacific Regional Fisheries Management Organisation in Law and Policy" (2011) 28:2 T M Cooley L Rev 181 at 183.

33 At 183.

${ }^{34}$ Global Ocean Commission, above n 1, at 5; Schiffman "The Evolution of Fisheries", above n 32, at 183.

${ }^{35}$ Schiffman "The Evolution of Fisheries", above n 32, at 183.

${ }^{36}$ At 183.
} 
requirements of developing states. ${ }^{37}$ However, conservation and management measures "are ultimately political and economic decisions". ${ }^{38}$

It should also be acknowledged that states are not required to use RFMOs to make decisions on the conservation and use of a fish stock. States can enter into direct arrangements with one another to achieve this aim. ${ }^{39}$ However, RFMOs have proved to be popular fora for cooperation. There are now around 18 RFMO's in operation, covering the majority of the world's marine fishery resources. ${ }^{40}$ Some date to the 1950 s and earlier, with most being established from 1980 onwards. $^{41}$

The 1995 United Nations Agreement on Straddling Fish and Highly Migratory Fish Stocks (FSA) has "significantly strengthened the position of RFMOs as the paradigm for the adoption of fisheries conservation and management measures". ${ }^{42}$ The FSA builds on existing provisions in the UNCLOS, expanding the obligation to co-operate through regional bodies. ${ }^{43}$ Specifically, the FSA obliges States to cooperate through either direct arrangements or through RFMOs for the conservation of straddling stocks and the conservation and optimum utilisation of highly migratory stocks. ${ }^{44}$ The FSA does not, however, cover discrete high seas fisheries, which are fish stocks found largely in the high seas, nor does it apply to fish stocks that are found completely within national jurisdiction. ${ }^{45}$ RFMOs can still regulate these fish stocks if that is provided for in their mandates, and, in respect of areas of within national jurisdiction, if they have the consent of the relevant coastal state. ${ }^{46}$

\footnotetext{
${ }^{37}$ Anderson et al., above n 9, at 19-20; and UNCLOS, art 119.

38 Ted L. McDorman "Decision-Making Processes of Regional Fisheries Management Organizations (RFMOs)" (paper presented to the Conference on Global High Seas Fisheries and the United Nations Fish Stocks Agreement, St Johns, Newfoundland, May 2005) at [20]; Schiffman, "The Evolution of Fisheries", above $\mathrm{n} 32$, at 183 .

${ }^{39}$ Rothwell and Stephens, above n 19, at 303-304; UNCLOS, art 63(2).

${ }^{40}$ Anderson et al., above $\mathrm{n} 9$, at XVIII.

${ }^{41}$ See Michael Lodge Managing International Fisheries: Improving Fisheries Governance by Strengthening Regional Fisheries Management Organisations (Chatham House, March 2007) at 3.

${ }^{42}$ Anderson et al., above $\mathrm{n} 9$, at VIII.

${ }^{43}$ Birnie et al. above n 3, at 733 .

${ }^{44}$ Agreement for the Implementation of the Provisions of the United Nations Convention on the Law of the Sea of 10 December 1982 relating to the Conservation and Management of Straddling Fish Stocks and Highly Migratory Fish Stocks [Fish Stocks Agreement] 2167 UNTS 3 (opened for signature 4 December 1995, entered into force 11 December 2001), arts 7-8.

${ }^{45}$ Rothwell and Stephens, above n 19, at 318.

${ }^{46}$ Pinto, above $\mathrm{n}$ 4, at 126.
} 


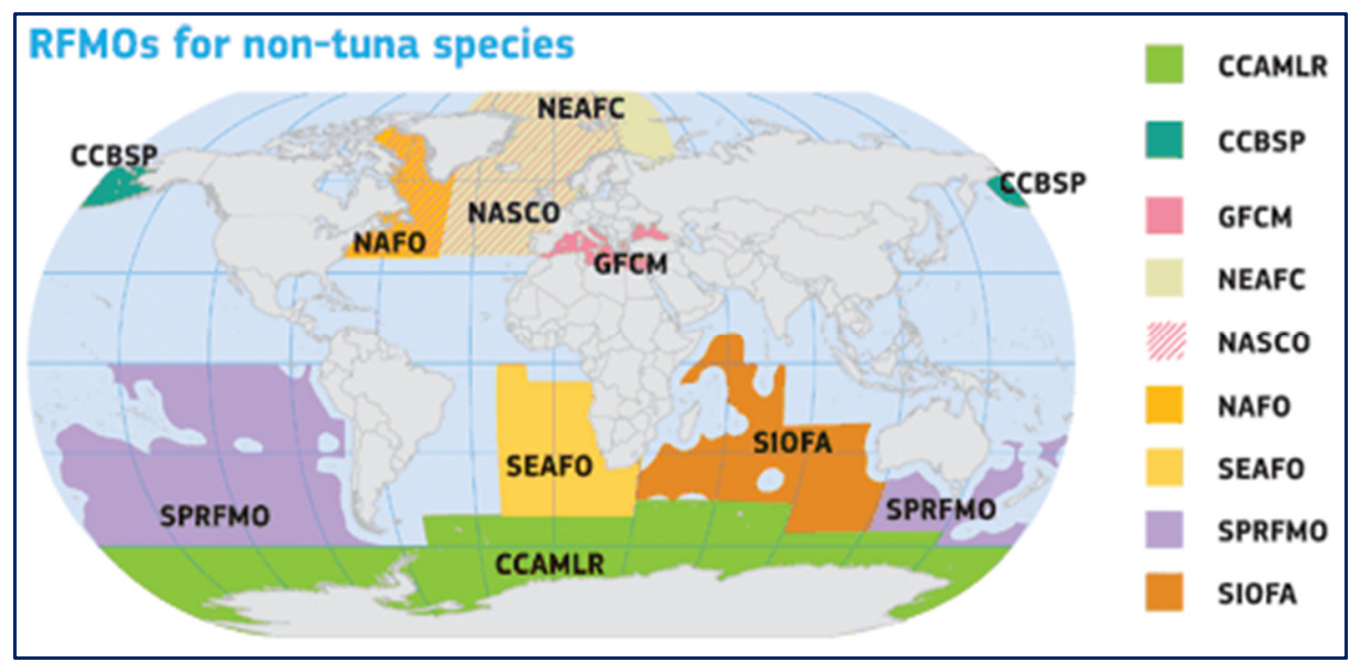

Figure One: Non-Tuna RFMOs (Source: European Commission)

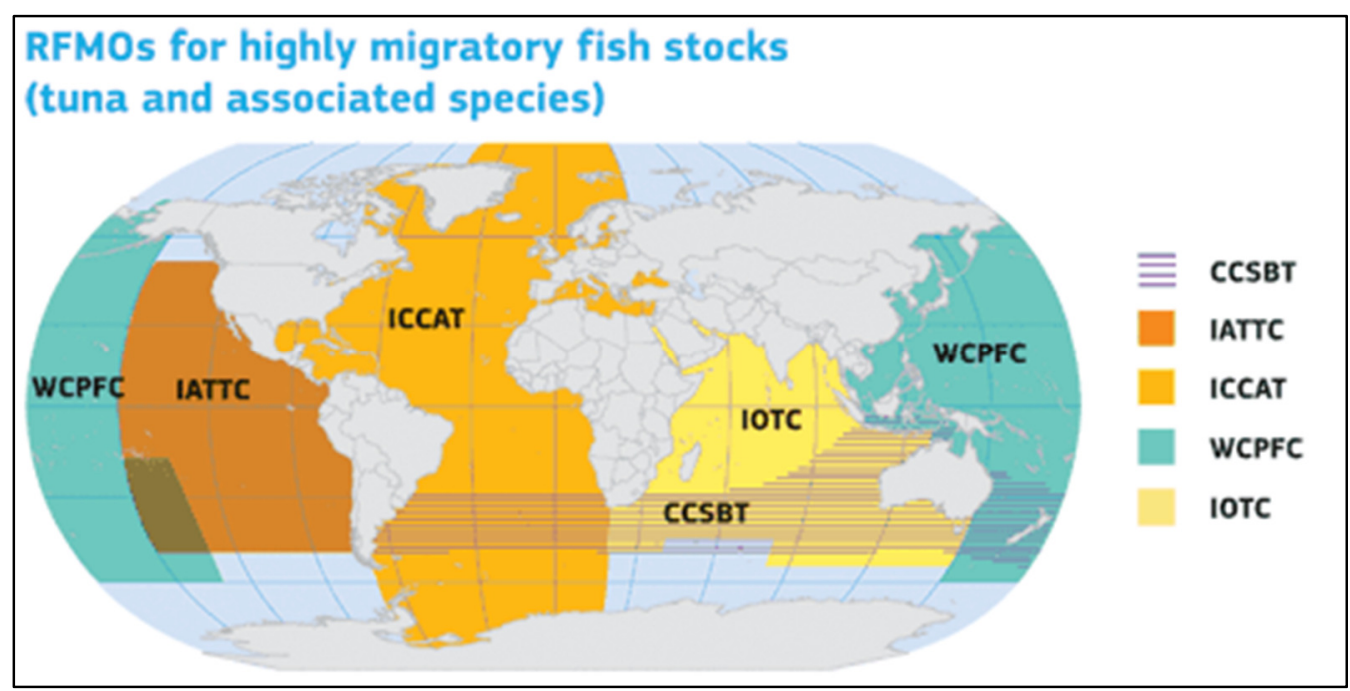

Figure Two: Highly-Migratory Species RFMOs (Source: European Commission)

Altogether, RFMOs are decision-making institutions. They do have other roles such as collecting fisheries statistics, assessing the state of fisheries resources, providing scientific 
advice, and monitoring activities. ${ }^{47}$ However, their key role as regulatory institutions is to facilitate decisions between States on managing and conserving fish stocks. These decisions walk a delicate tightrope between satisfying the economic interests of states in fishing as well as trying to conserve and protect these living resources, and associated ecosystems. As such, it is important that the decision-making processes of each of these RFMOs work towards, rather than against, producing effective decisions.

\section{Effective RFMO Decision-Making}

RFMOs evidently have an important role in the law of the sea, and central to that role are the decisions these institutions make. However, several commentators and reports have identified decision-making procedures as impediments to the effectiveness of regional fisheries management organisations. ${ }^{48}$ Indeed, the core contention of this paper is that particular aspects of RFMO decision-making processes can undermine effective conservation and management decisions, and that SPRFMO offers a decision-making model that could help make RFMOs more effective. Therefore a definition of what is meant by an effective decision-making process needs to be established. This will help with exploring issues that are making RFMO decision-making processes less effective, and with evaluating options for reform.

Effectiveness can simply be defined "as the degree to which something is successful in producing a desired result". ${ }^{49}$ In the context of RFMOs, the desired results are conservation and management measures that achieve the objectives of their conventions as well as those of other law of the sea instruments. ${ }^{50}$ For example, UNCLOS establishes that States taking conservation measures for living resources in the high seas shall, amongst other things: ${ }^{51}$

\footnotetext{
${ }^{47}$ FAO Fisheries and Aquaculture Department "Governance of High Seas Fisheries" (2014) Food and Agriculture Organization of the United Nations <www.fao.org $>$.

${ }^{48}$ Tore Henriksen, Geir Hønneland and Are Sydnes Law and Politics in Ocean Governance: The UN Fish Stocks Agreement and Regional Fisheries Management Regimes (Martinus Nijhoff Publishers, Ledien 2006) at 204; FAO Fisheries and Aquaculture Department, above n 14, at 69; McDorman, above n 38, at [2]; Robin Warner, above n 11, at 125-126; Schiffman Marine Conservation, above n 30.

49 Oxford University "Oxford Dictionaries: Definition of Effectiveness" (2014) Oxford Dictionaries $<$ www.oxfordictionaires.com>.

${ }^{50}$ Cullis-Suzuki and Pauly "Failing the High Seas", above n 7, at [5].

${ }^{51}$ UNCLOS, art 119(1)(a).
} 
take measures which are designed, on the best scientific evidence available to the States concerned, to maintain or restore populations of harvested species at levels which can produce the maximum sustainable yield.

Meanwhile, the FSA obliges States to "adopt measures to ensure long-term sustainability of straddling fish stocks and highly migratory fish stocks and promote the objective of their optimum utilization". ${ }^{52}$ Most RFMO Conventions have objectives similar to these statements. $^{53}$ If it could be established that RFMOs were meeting these high-level objectives, then it could be argued that the RFMO's are effective institutions. ${ }^{54}$ Thereby their decision-making process must also be effective. However, the reality is that RFMOs are generally not achieving outcomes such as fish stock sustainability. ${ }^{55}$ Indeed, whilst there are difficulties obtaining definitive data on the current state of high seas fisheries, the most recent FAO assessment found that 60 per cent of straddling and high seas stocks and thirty per cent of tuna stocks were overexploited. ${ }^{56}$

The 2010 Cullis-Suzuki and Pauly study into the effectiveness RFMOs suggests there is much to be concerned about with RFMOs in particular. According to the study's methodology paper, "the effectiveness of current RFMOs has never been comprehensively assessed", an omission it aimed to address. ${ }^{57}$ The study's global evaluation of RFMO effectiveness was based on a two-tiered approach. ${ }^{58}$ It first looked at how RFMOs performed "on paper", and then into how RFMOs were performing "in practice". 59

The 'on paper' score looked into how well RFMOs were incorporating 26 different best practice criteria, as established by the Independent Panel to Develop a Model for Improved Governance by Regional Fisheries Management Organisations (the Chatham House Panel). ${ }^{60}$ The authors found an average score of $57 \%$ performance against theoretical best practice, evidently leaving considerable room for improvement. However, the 'in practice'

\footnotetext{
${ }^{52}$ Fish Stocks Agreement, art 5(a).

${ }^{53}$ Cullis-Suzuki and Pauly, above n 7, at [5].

${ }^{54}$ At [5].

${ }^{55}$ See Cullis-Suzuki and Pauly, above $\mathrm{n} 7$.

${ }^{56}$ Csirke et al., above $\mathrm{n} 8$, at [9.1].

57 Sarika Cullis-Suzuki and Daniel Pauly Evaluating Global Fisheries Management Organizations: Methodology and Scoring (University of British Columbia Fisheries Centre, Working Paper 2009-12, 2009)

at 2 .

${ }^{58}$ At 3 .

${ }^{59}$ At 3 .

${ }^{60}$ At 4.
} 
score was even more worrying. It evaluated how well stocks actually do under RFMO management, looking at current stock biomass and performance through time. Of the 14 RFMOs studied for this exercise, the average score was $49 \%$ performance. The authors noted the establishment of an RFMO in most cases "did not seem to have visible positive effect on stock biomass", indeed the trend was one of decline. ${ }^{61}$ Perversely, "in many cases, severe stock declines occurred after an RFMO was established". ${ }^{62}$

The Cullis-Suziki and Pauly study demonstrates that RFMO's can hardly be labelled as 'effective' organisations. However, determining the degree of causation between decisionmaking processes and RFMO effectiveness is problematic. This is because there are a variety of causative factors behind fish stock decline ${ }^{63}$ Although structural and governance weaknesses have been implicated as a challenge confronting RFMOs, they could theoretically be deciding on best practice measures only to be defeated by poor enforcement, illegal fishing and pollution. ${ }^{64}$

Another more fundamental issue arguably lies with the nature of the international law of the sea itself. On the high seas a fundamental principle is that of exclusive flag state jurisdiction. ${ }^{65} \mathrm{~A}$ fishing vessel operating on the high seas is prima facie "only subject to the jurisdiction of the state whose flag they fly". ${ }^{66}$ Whilst the duty to cooperate in the conservation and management of living resources is "widely accepted as a customary principle of international environmental law", ${ }^{67}$ the content of the duty to co-operate in international customary law has not clearly developed to stage where non-RFMO participants are required to apply an RFMO's conservation and management measures. ${ }^{68}$ The FSA does provide that States only discharge their duty of co-operation by either joining the RFMO of a relevant fishery or by agreeing to apply the conservation and management

\footnotetext{
${ }^{61}$ Cullis-Suzuki and Pauly Evaluating Global Fisheries, above n 57, at 12-13.

${ }^{62}$ Pew Environment Group High Seas Management Gets Low Marks: A Summary of a New Scientific Analysis (Pew Environment Group, May 2010) at 4.

${ }^{63}$ See Secretary-General of the United Nations, above n 2, at 16-17.

${ }^{64}$ Global Ocean Commission, above $\mathrm{n} 1$, at 1.

${ }^{65}$ Clark, above n 6, at 225; Warner, above n 11, at 35-38; UNCLOS, pt VII.

${ }^{66}$ Clark, above $\mathrm{n} 6$, at 225.

${ }^{67}$ At 223.

${ }^{68}$ At $230-244$.
} 
measures established by the organisation. ${ }^{69}$ The problem is that only a relatively small a States are party to the FSA. ${ }^{70}$

If a state has not ratified the FSA or if they are not a member of a particular RFMO, they are not explicitly obliged to implement a particular RFMO's measures in respect of straddling and highly migratory stocks. ${ }^{71}$ This inability to compel compliance from ships operating under the jurisdiction of non-RFMO and non-FSA member states can undermine the effectiveness of RFMO conservation and management regimes. ${ }^{72}$ Indeed, IUU fishing does seriously undermine the effectiveness of RFMOs. ${ }^{73}$

Altogether, it is evident that RFMO decision-making effectiveness cannot simply be determined by looking to what extent the RFMO is meeting its own treaty objectives and those of other international instruments. Problems with RFMO decision-making are simply one of a multitude of other issues. Another set of evaluative criteria is therefore needed. Fortunately, in confronting the same problem of what is meant by an effective RFMO decision-making process, McDorman has developed a more holistic set out of criteria to establish effectiveness. This is in relation to what he calls "decision adoption procedures". 74 This criteria has three elements. For a decision to be effective, the decision must be: ${ }^{75}$
a) Acceptable to RFMO members;
b) Made in a timely manner; and
c) It must be conservation orientated.

In the article where McDorman outlines these criteria he does not elaborate on why these particular characteristics were chosen. ${ }^{76}$ However, it can be assumed that acceptability is important as greater support for a decision "is expected to result in better compliance and implementation". ${ }^{77}$ Moreover, a decision that has broad acceptance is unlikely to be

\footnotetext{
${ }^{69}$ Fish Stocks Agreement art 8(3).

${ }^{70}$ Kristen E Boon "Overfishing of Bluefin Tuna: Incentivising Inclusive Solutions" (2013) 52 U Louisville

L Rev 1 at 12; and Pinto, above $\mathrm{n}$ 4, at 129.

${ }^{71}$ Meltzer, above n 14, at 189.

${ }^{72}$ At 12.

${ }^{73}$ Yoshifumi Tanaka The International Law of the Sea (Cambridge University Press, Cambridge, 2012) at [6.1].

${ }^{74}$ McDorman, above n 38, at [13].

${ }^{75}$ At [13].

${ }^{76}$ See McDorman, above $\mathrm{n} 38$.

${ }^{77}$ Meltzer, above n 14, at 8.4.3.
} 
disputed by an RFMO participant or cause division within an RFMO that could hamper timely decision-making.

Timely decision-making is an important characteristic on its own. ${ }^{78}$ It provides certainty and helps ensure the coherency of the management regime. If decisions are delayed this may leave gaps in the conservation regime, and undermine the efficacy of the RMFO's conservation measures. ${ }^{79}$ Additionally, conservation orientation is essential, otherwise the decision itself will do little to help ensure that a fish stock is sustainably harvested. This criterion goes to the very purpose of RFMO's as vehicles for conservation and management decisions. ${ }^{80}$ Altogether, if any of the criteria are missing from a decision it follows that the effectiveness of the decision would be adversely affected. Therefore McDorman's three criteria are arguably necessary conditions for effective decision-making, thereby providing a useful normative framework for evaluating RFMO practice.

There are other desirable elements that can added to McDorman's criteria. Firstly, the principle that States are only bound by treaties to which they are party means it is important that RFMOs be designed to encourage wide participation. ${ }^{81}$ As was noted above, nonparticipants can undermine the efficacy of RFMO measures. McDorman notes that even if a State has ratified the FSA, "some States have strong views on whether a particular decision-making process will result in the attainment of their interests". ${ }^{82}$ Consequently, the design of effective decision-making procedures needs to account for how it will impact on participation in the regime.

Another desirable characteristic is transparency. ${ }^{83}$ The exact value of transparency has been questioned, with Barrett arguing it can in fact undermine co-operation. ${ }^{84}$ Indeed, it is arguably not a necessary condition for producing effective decisions. However, by opening decisions to third-party scrutiny, transparency also brings greater accountability to the decision-making process, thereby improving effectiveness. ${ }^{85}$ Regardless, it is also

\footnotetext{
${ }_{78}$ Anderson et al., above $\mathrm{n} 9$, at 40-41.

${ }^{79}$ See Meltzer, above $\mathrm{n}$ 14, at [8.4.4.3].

${ }^{80}$ Anderson et al, above $\mathrm{n} 9$, at 1 .

${ }^{81}$ Meltzer, above n 14, at 199.

${ }^{82}$ McDorman, above n 38, at [4].

${ }^{83}$ Meltzer, above n 14, at [8.4].

${ }^{84}$ Scott Barrett Environment and Statecraft: The Strategy of Environmental Treaty-Making (Oxford, Oxford University Press, 2003) at 145-146.

${ }^{85}$ Meltzer, above n 14, at 201.
} 
mandated by Article 12 of the FSA. ${ }^{86}$ Transparency will therefore be accounted for in evaluating SPRFMO's processes later in this paper.

\section{Key Issues in RFMO Decision-Making}

Effective RFMO decision-making is not just a desirable for goal for RFMOs. The FSA in fact obliges States to "agree on decision-making procedures which facilitate the adoption of conservation and management measures in a timely and effective manner". ${ }^{87}$ Additionally, in order to prevent disputes, the FSA provides that "States shall agree on efficient and expeditious decision-making procedures ... and shall strengthen existing decision-making procedures as necessary" ${ }^{88}$ However, the Cullis-Suzuki and Pauly study concludes that most RFMOs are failing to produce effective decisions. ${ }^{89}$ They are, therefore, out of step with these international norms. Accordingly, solutions are needed. Yet, before assessing the extent to which SPRFMO offers a cure for defective decisionmaking processes, it is important to first identify the key issues facing RFMO decisionmaking.

It must first be made clear that this paper is focusing on substantive rather than procedural RFMO decisions. The Chatham House Panel's report into RFMO best practice divides RFMO decision-making into these two categories. ${ }^{90}$ Substantive decisions relate to conservation and management measures which "are at the heart of the work of RFMOs". 91 Whilst procedural decisions, such as the adoption of budgets, are certainly important to the functioning of RFMOs as organisations, they are of secondary importance to the conservation and management goals of these organisations. ${ }^{92}$

The Chatham House Panel also identifies two components to substantive decision-making. These are the processes and criteria used for adopting a decision. ${ }^{93}$ Decision-making criteria includes taking account matters such as scientific advice, the precautionary approach and any conservation measures already implemented by coastal states. ${ }^{94}$ In contrast, process includes matters such the required level of support as well as objection

\footnotetext{
${ }^{86}$ Fish Stocks Agreement, art 12.

${ }^{87}$ Art 10(j).

${ }^{88}$ Art 28.

${ }^{89}$ Cullis-Suzuki and Pauly "Failing the High Seas, above n 7, at [5].

${ }^{90}$ Anderson et al., above $\mathrm{n} 9$, at 70 .

${ }^{91}$ At 70.

${ }^{92}$ At 70.

${ }^{93}$ At 70 .

${ }^{94}$ SPRFMO Convention, arts 3-4.
} 
procedures, ${ }^{95}$ which are "intimately tied to formal procedures for decision adoption in many RFMOs". 96

Both process and criteria are important to producing effective decisions. Indeed, a decisionmaking process can be rapid and fully accepted by an RFMO's member states, but may not actually achieve the conservation and management goals of these organisations unless it is informed by scientific advice and key guiding principles. ${ }^{97}$ Indeed, the fact that RFMOs scored, on average, only 5.4 out of 10 for their application of the precautionary approach in the Cullis-Suzuki and Pauly study does suggest there is real scope for improvement in this area. ${ }^{98}$ However, the core focus of this paper will be on the decision-making process itself. This is both because the particularly novel feature of SPRFMO is its decision-making process, and also to allow for sufficient discussion of the issues confronting RFMO decision-making processes within the context of this paper. ${ }^{99}$

For the purposes of this discussion, the decision-making process will be broken into its two core components. Firstly, it will look at problems associated with the level of support needed to adopt a decision, otherwise termed as decision-adoption procedures. ${ }^{100}$ The main issue in this area are the negative impacts of consensus or unanimity-based decisionmaking. Secondly, it will examine issues associated with objection procedures. This will find that excessive use of objection procedures can be a significant problem for decision efficacy.

\section{A Decision-Making Based on Consensus and Unanimity}

The level of support needed for a proposal to become a binding decision of an RFMO's commission is a crucial aspect of the decision-making process. Whilst there are a variety of methods used by RFMOs, Table One (below) shows the trend is to require decisions to be adopted by consensus or by unanimous voting. ${ }^{101}$ Even where consensus is not formally required, general RFMO practice is to seek consensus. ${ }^{102}$ Consensus in RFMO treaties is typically defined as the absence of an objection when a decision is made. ${ }^{103}$ In contrast,

\footnotetext{
95 Anderson et al., above $\mathrm{n} 9$, at 74.

${ }^{96}$ McDorman above n 38, at [14].

${ }^{97}$ Anderson et al., above $\mathrm{n}$ 9, at 76-77.

${ }^{98}$ Pew Environment Group, above n 62, at 3.

99 Joanna Mossop "Law of the Sea and Fisheries" (2009) 7 NZYIL 336 at 336 and 338.

${ }^{100}$ See McDorman, above n 38, at [2.1].

101 At [11].

102 At [10].

103 Anderson et al., above n 9, at 74.
} 
unanimity generally requires every State to formally vote for a measure for it to pass. ${ }^{104}$ Both procedures can work towards undermining the effectiveness of the decision-making process.

\begin{tabular}{|c|c|c|c|}
\hline RFMO & Procedure & RFMO & Procedure \\
\hline IPHC (1923) & Consensus. ${ }^{107}$ & PSC (1985) & Consensus $^{108}$ \\
\hline IATTC (1950) & Consensus. ${ }^{109}$ & NPAFC (1993) & Consensus. $^{110}$ \\
\hline GFCM (1952) & $2 / 3$ majority vote. ${ }^{111}$ & CCSBT (1994) & Unanimous vote. $^{112}$ \\
\hline ICCAT (1969) & $2 / 3$ majority vote. $^{113}$ & CCBSP (1996) & Consensus. ${ }^{114}$ \\
\hline IBSFC (1974) & $\begin{array}{l}2 / 3 \text { majority vote. } \\
115\end{array}$ & IOTC (1996) & Simple majority. ${ }^{116}$ \\
\hline
\end{tabular}

\footnotetext{
${ }^{104}$ Meltzer, above n 14, at 191-192.

${ }^{105}$ By most recent in force Convention, and substantive decisions only. Table concept derived from Pinto, above $\mathrm{n} 4$, at 130 .

${ }^{106}$ Derived from Lodge, above n 42, at 3.

${ }^{107}$ Convention between the United States of America and Canada for the Preservation of the Halibut Fishery of the Northern Pacific Ocean and Bering Sea [IPHC Convention] 222 UNTS 77 (signed 2 March 1953, entered into force 28 October 1953), art III.

108 Treaty Between the Government of Canada and the Government of the United States of America Concerning Pacific Salmon [PSC Treaty] 1469 UNTS 358 (signed 28 January 1985, entered into force 18 March 1985), art II(6)

109 Convention for the Strengthening of the Inter-American Tropical Tuna Commission Established by the 1949 Convention between the United States of America and the Republic of Costa Rica UST [Antigua Convention] available at http://www.iattc.org/PDFFiles2/Antigua_Convention_Jun_2003.pdf (Opened for signature November 14 2003, entered into force August 27 2007), art IX(3).

${ }^{110}$ Convention for the Conservation of Anadromous Stocks in the North Pacific Ocean [NPAFC Convention] (Signed 11 February 1992, entered into force 16 February 1993), art VII(10).

${ }^{111}$ Agreement for the establishment of a General Fisheries Council for the Mediterranean as amended by the General Fisheries Council for the Mediterranean [GFCM Convention] 2275 UNTS 157 (6 November 1997), art $\mathrm{V}(1)$.

${ }^{112}$ Convention for the Conservation of Southern Bluefin Tuna [CCBST Convention] 1819 UNTS 360 (opened for signature 10 May 1993, entered into force 20 May 1994), art 7.

${ }^{113}$ International Convention for the Conservation of Atlantic Tunas [ICCAT Convention] 673 UNTS 63 (signed 14 May 1966, entered into force 21 March 1966), art VIII.

${ }^{114}$ Convention on the Conservation and Management of Pollock Resources in the Bering Sea [CCBSP Convention] 34 ILM 67 (opened for signature 16 June 1994, entered into force 8 December 1995), art V.

${ }^{115}$ Convention on Fishing and Conservation of the Living Resources in the Baltic Sea and the Belts [IBSFC Convention] 1090 UNTS 93 (signed on 13 September 1973, entered into force 28 July 1974), art VIII(3).

${ }^{116}$ Agreement for the Establishment of the Indian Ocean Tuna Commission [IOTC Convention] 1927 UNTS 329 (signed 25 November 1993, entered into force March 27 1996), art IX(1).
} 


\begin{tabular}{|l|l|l|l|}
\hline NAFO (1979) & 2/3 majority vote. ${ }^{117}$ & SEAFO (2003) & 2/3 majority vote. ${ }^{118}$ \\
\hline CCAMLR (1982) & Consensus. ${ }^{119}$ & WCPFC (2004) & $\begin{array}{l}\text { 3/4 vote, if consensus } \\
\text { cannot be reached. }{ }^{120} \\
\text { Consensus if on } \\
\text { 'consensus list'. }{ }^{121}\end{array}$ \\
\hline NEAFC (1982) & $\begin{array}{l}2 / 3 \text { majority vote. } \\
122\end{array}$ & SIOFA (2012) & Consensus. $^{123}$ \\
\hline NASCO (1983) & Unanimous vote. ${ }^{124}$ & SPRFMO (2012) & $\begin{array}{l}3 / 4 \text { vote, if consensus } \\
\text { cannot be reached. }\end{array}$ \\
\hline
\end{tabular}

Firstly, there is a distinction between unanimity and consensus-based decision-making. ${ }^{126}$ The former is vote-based. This can be advantageous "as the issue is resolved at a specific point in time. By putting a question to a vote, positions of the participants are clarified and polled, and a decision is finally taken." 227 In contrast, the consensus approach "may involve protracted discussion or intractable parties, which can lead to stalemates and paralysis". ${ }^{28}$ Conversely, vote-based decision-making "may create contending factions within the

${ }_{117}$ Convention on Future Multilateral Co-operation in the Northwest Atlantic Fisheries [NAFO Convention] 1135 UNTS 369 (signed 24 October 1978, entered into force January 1 1979), art XIV(2).

${ }^{118}$ Convention on the Conservation and Management of Fishery Resources in the South-East Atlantic Ocean [SEAFO Convention] 2221 UNTS 91 (opened for signature 20 April 2001, entered into force 17 May 2001), art 17.

119 Convention on the Conservation of Antarctic Marine Living Resources [CCAMLR Convention] 1329 UNTS 47 (opened for signature 20 May 1980, entered into force 7 April 1982), art XII.

${ }^{120}$ Convention on the Conservation and Management of Highly Migratory Fish Stocks in the Western and Central Pacific [WCPFC Convention] 2004 ATS 15 (opened for signature 5 September 2000, entered into force 19 June 2004), art 20.

${ }^{121}$ Convention on the Conservation and Management of Highly Migratory Fish Stocks in the Western and Central Pacific Ocean [WCPFC Convention] 2275 UNTS 43 (signed 5 September 2000, entered into force 19 June 2004), art 10(4).

${ }^{122}$ Convention on Future Multilateral Co-operation in North-East Atlantic Fisheries [NEAFC Convention] 1285 UNTS 130 (signed 18 November 1980, entered into force 17 March 1982), art 3(9) and 5.

123 Southern Indian Ocean Fisheries Agreement (SIOFA Convention) available at http://www.fao.org/fileadmin/user_upload/legal/docs/2_035t-e.pdf (opened for signature 7 July 2006, entered into forced 21 June 2012), art 8.

${ }^{124}$ Convention for the Conservation of Salmon in the North Atlantic Ocean [NASCO Convention] 1338

UNTS 34 (signed 2 March 1982, entered into force 1 October 1983), art 11(3).

${ }^{125}$ SPRFMO Convention, art 16.

${ }^{126}$ Meltzer, above n 14, at [8.4.3.1]; and Schiffman Marine Conservation, above n 30, at 111-122.

${ }^{127}$ Meltzer, above $\mathrm{n}$ 14, at [8.4.3].

${ }^{128}$ At [8.4.3]. 
organization, or trigger, where available, the use of the objection procedure".${ }^{129}$ However, despite the "dynamics" of the procedures being different, as both methods essentially require all members of an RFMO to consent to a decision, they will be treated as the same for the purposes of this discussion. ${ }^{130}$

On one hand, consensus and unanimity ensure that the decision is at least acceptable to all States. This is consistent with the principle of international law that States are generally only bound by decisions to which they assent. ${ }^{131}$ On the other hand, both have "been criticized for leading to protracted decision making, paralysis or diluted conservation measures". ${ }^{132}$ In 2008 the FAO specifically identified the use consensus-based decisionmaking as a component of RFMO frameworks that was impairing their effectiveness. ${ }^{133}$

Where unanimity and consensus are required, any member of the RFMO can exercise a "de facto veto" over the process, and possibly demand concessions that undermine the conservation effect of a decision and its acceptability to other members. ${ }^{134}$ Even if a decision is reached: ${ }^{135}$

the final outcome acceptable to all States may be considerably below the conservation standard required to avoid overfishing, rebuild fish stocks, and rehabilitate critical habitat. As a result, RFMO management decisions are often based on the "lowest common denominator" and do not necessarily meet the international minimum standard for effective management.

One extreme example of the negative consequences of a unanimity requirement can be found in the history of the Commission for the Conservation of Southern Bluefin Tuna (CCSBT). Schiffman observes that the unanimity requirement in the CCSBT was "beyond any doubt, in the mid to late 1990s ... a major limitation on the work of the regime". ${ }^{136}$ For many years the CCSBT Commission was unable to establish a TAC for southern Bluefin tuna. ${ }^{137}$ This is a fish stock that was, and still remains, a listed critically endangered

\footnotetext{
${ }^{129}$ Meltzer, above n 14, at [8.4.3], at [8.4.3].

${ }^{130}$ Meltzer, above n 14, at [8.4.3.1]; and Schiffman Marine Conservation, above n 30, at 112.

${ }^{131}$ McDorman, above n 38, at [4].

132 Meltzer, above $\mathrm{n}$ at 186

${ }^{133}$ FAO Fisheries and Aquaculture Department State of World Fisheries, above n 10, at 69.

134 Anderson et al, above $\mathrm{n} 9$, at 73.

135 Meltzer, above n 14, at [8.4.4.3].

136 Schiffman Marine Conservation, above n 30, at 120.

${ }^{137}$ Rothwell and Stephens, above n 19, at 305.
} 
species. ${ }^{138}$ From 1994 onwards Japan wanted to increase the TAC and its catch allocation, as well as establish an experimental research program above its catch allocation. ${ }^{139}$ New Zealand and Australia opposed these proposals. When Japan decided to persist with its research proposals in 1998, this precipitated international litigation before International Tribunal on the Law of the Sea. ${ }^{140}$ The unanimity requirement had, therefore, created an impasse in the regime, undermining efforts to restore a badly depleted fish stock and generating division amongst its members. ${ }^{141}$

A requirement for consensus or unanimity does not necessarily result in an ineffective decision-making process. The Commission of the Conservation of Antarctic Marine Living Resources' (CCAMLR) 2012 Performance Review Panel stated that its consensus-based decision-making model had worked well. ${ }^{142}$ However, the Performance Review Panel qualified this conclusion by "stating the consensus rule in the implementation of some conservation measures had nevertheless created problems, and the potential for conflict was growing in this respect". ${ }^{143}$ Indeed, Joyner has argued in the context of CCAMLR that "consensus-based decision-making can carry too exorbitant a price", with consensus paralysing CCAMLR for more than half a decade in the 1980s. ${ }^{144}$

As with CCAMLR's reviewers, Schiffman makes similarly qualified observations about the use of consensus in the Indian Ocean Tuna Commission (IOTC) and the North Atlantic Salmon Commission (NASCO). In context of the IOTC, he first noted that the organisation had "impressively" adopted all substantive decisions by consensus. ${ }^{145}$ However, he went on to say "this observation must be tempered, however, with the likelihood that consensus is being achieved at the lowest level of common agreement". ${ }^{146}$ Schiffman also made

\footnotetext{
${ }_{138}$ Rothwell and Stephens, above n 19, at 305.

${ }^{139}$ At 305; and Schiffman Marine Conservation, above n 30, at 121-123

${ }^{140}$ Schiffman Marine Conservation, above n 30, at 121-123; and Rothwell and Stephens, above n 19, 305.

${ }^{141}$ Schiffman Marine Conservation, above n 30, at 124-126

${ }^{142}$ Marika Ceo, Sarah Fagnani, Judith Swan, Kumiko Tamada and Hiromoto Watanabe Performance Reviews by Regional Fishery Bodies: Introduction, Summaries, Synthesis and Best Practices (Food and Agriculture Organization of the United Nations, FAO Fisheries and Aquaculture Circular No. 1072, 2012) at 14.

${ }^{143}$ At 69.

${ }^{144}$ Christopher C. Joyner, Governing the Frozen Commons: The Antarctic Regime and Environmental Decision-Making (University of South Carolina Press, Columbia, 1998) at 127; and Schiffman Marine Conservation, above n 30, at 154.

${ }^{145}$ Schiffman Marine Conservation, above n 30, at 77.

${ }^{146}$ At 77
} 
similar observations in respect of the NASCO, adding that unanimity had typically slowed down its decision-making process. ${ }^{147}$

The examples and observations above illustrate the impact consensus-based decisionmaking can have on decision-making efficacy. Evidently, it can undermine decision timeliness and conservation orientation. Moreover, the deadlock in the CCSBT demonstrates how it can paralyse the work of an RFMO. Taken together, the examples establish why RFMOs must take steps to mitigate these risks if they are to ensure the efficacy of their processes.

\section{B Objection Procedures}

Objection procedures are mechanisms that allow a member State to "prevent a conservation measure adopted under a treaty regime from applying to" them. ${ }^{148}$ Objections typically have to be made within a set period of time following a State being notified of a decision, and, often, if enough members object, a decision will cease to be binding on all RFMO members. ${ }^{149}$

RFMOs have a "long tradition of allowing parties to object to, and opt out of, decisions they deem undesirable". ${ }^{150}$ Schiffman identifies this as a major factor behind the lack of success of many RFMOs. ${ }^{151}$ As Table Two (below) demonstrates, the majority of RFMOs have procedures in place allowing states to opt-out of conservation and management measures. Interestingly, they are common amongst RFMOs who have consensus or unanimity-based decision-making, where every member would have already assented to a decision. ${ }^{152}$ This particular combination has been called a "double-veto". ${ }^{153}$

\footnotetext{
${ }^{147}$ Schiffman Marine Conservation, above n 30, at 134-135.

148 At 5.

${ }^{149}$ Meltzer, above n 14, at [8.4.5].

${ }^{150}$ Schiffman "The South Pacific Regional Fisheries Management Organisation”, above n 16, at 211.

${ }^{151}$ At 211.

${ }^{152}$ Meltzer, above n 14, at [8.4.5].

${ }^{153}$ Olav Schram Stokke The Effectiveness of CCAMLR in Governing the Antarctic: The Effectiveness and Legitimacy of the Antarctic Treaty System (Cambridge, Cambridge University Press, 1996) at 142 as cited in Schiffman, above n 30, at 153.
} 


\begin{tabular}{|c|c|c|c|}
\hline \multicolumn{4}{|c|}{ Table Two: Objection Procedure in 18 RFMOs $^{154}$ (Year Established) ${ }^{155}$} \\
\hline RFMO & $\begin{array}{l}\text { Objection } \\
\text { Procedure }\end{array}$ & RFMO & Objection Procedure \\
\hline IPHC (1923) & No procedure. ${ }^{156}$ & PSC (1985) & No procedure. ${ }^{157}$ \\
\hline IATTC (1950) & No procedure. ${ }^{158}$ & NPAFC (1993) & No procedure. ${ }^{159}$ \\
\hline GFCM (1952) & Yes. ${ }^{160}$ & CCSBT (1996) & No procedure. ${ }^{161}$ \\
\hline ICCAT (1969) & $\begin{array}{l}\text { Yes but } \quad \text { must } \\
\text { reaffirm. }{ }^{162}\end{array}$ & CCBSP (1996) & No procedure. ${ }^{163}$ \\
\hline IBSFC (1974) & Yes. ${ }^{164}$ & IOTC (1996) & Yes. ${ }^{165}$ \\
\hline NAFO (1979) & Yes. ${ }^{166}$ & SEAFO (2003) & $\begin{array}{l}\text { Yes, but must provide } \\
\text { reasons and there is the } \\
\text { possibility of review } \\
\text { and binding interim } \\
\text { measures. }{ }^{167}\end{array}$ \\
\hline CCAMLR (1982) & $\begin{array}{l}\text { Yes, decision can } \\
\text { also be reviewed by } \\
\text { Commission on } \\
\text { request. }\end{array}$ & WCPFC (2004) & $\begin{array}{l}\text { No, but decision can } \\
\text { be independently } \\
\text { reviewed on limited } \\
\text { grounds. }{ }^{169}\end{array}$ \\
\hline NEAFC (1982) & Yes. ${ }^{170}$ & SIOFA (2012) & No. ${ }^{171}$ \\
\hline
\end{tabular}

\footnotetext{
${ }^{154}$ Per most recent in force treaty. Table concept derived from Diz Pereira Pinto, above n 4105, at 130.

155 Derived from Lodge, above n 42, at 3.

156 IPHC Convention.

157 PSC Convention.

158 Antigua Convention, art IX.

159 NPAFC Convention.

${ }^{160}$ GFCM Convention, art V(3).

${ }^{161}$ CCBST Convention.

162 ICCAT Convention, art VIII(3).

${ }^{163}$ CCBSP Convention.

164 IBSFC Convention, art XI.

165 IOTC Convention, art IX(5).

${ }^{166}$ NAFO Convention, art XII.

167 SEAFO Convention, art 23.

168 CCAMLR Convention, art IX(6).

169 WCPFC Convention, art 20(6).

${ }^{170}$ NEAFC Convention, art 12.

${ }^{171}$ SIOFA Convention, art 8.
} 


\begin{tabular}{|l|l|l|l|}
\hline NASCO (1983) & Yes $^{172}$ & SPRFMO (2012) & $\begin{array}{l}\text { Yes, on limited } \\
\text { grounds Automatic } \\
\text { independent review } \\
\text { and equivalent } \\
\text { measures must be } \\
\text { adopted. }{ }^{173}\end{array}$ \\
\hline
\end{tabular}

The Chatham House Panel has labelled objection procedures an "unusual feature" of RFMOs, ${ }^{174}$ noting "there is no procedure for objecting to a binding decision of the Security Council under Chapter VII of the UN Charter". ${ }^{175}$ Objections can be analogised to treaty reservations. ${ }^{176}$ Both have similar rationales: to encourage "participation in treaty regimes by a wider range of states than might otherwise be possible."177

Whilst not as potentially damaging as a veto which can "block a measure from coming into existence in the first instance", ${ }^{178}$ objections "prevent a conservation measure adopted under the treaty regime from applying to a treaty member" ${ }^{\prime \prime 79}$. Thereby, if the objector is allowed to set their own measures as a result, they can limit the conservation effect of a decision. Although, not all objections will undermine the conservation regime. ${ }^{180}$ Furthermore, the acceptability of the decision to which States find themselves bound may diminish when they see other RFMO members establishing their own unilateral measures. ${ }^{181}$

International law places several caveats on the use of objection procedures. ${ }^{182}$ Just as general reservations should not interfere with the object and purpose of a treaty, ${ }^{183}$ the use

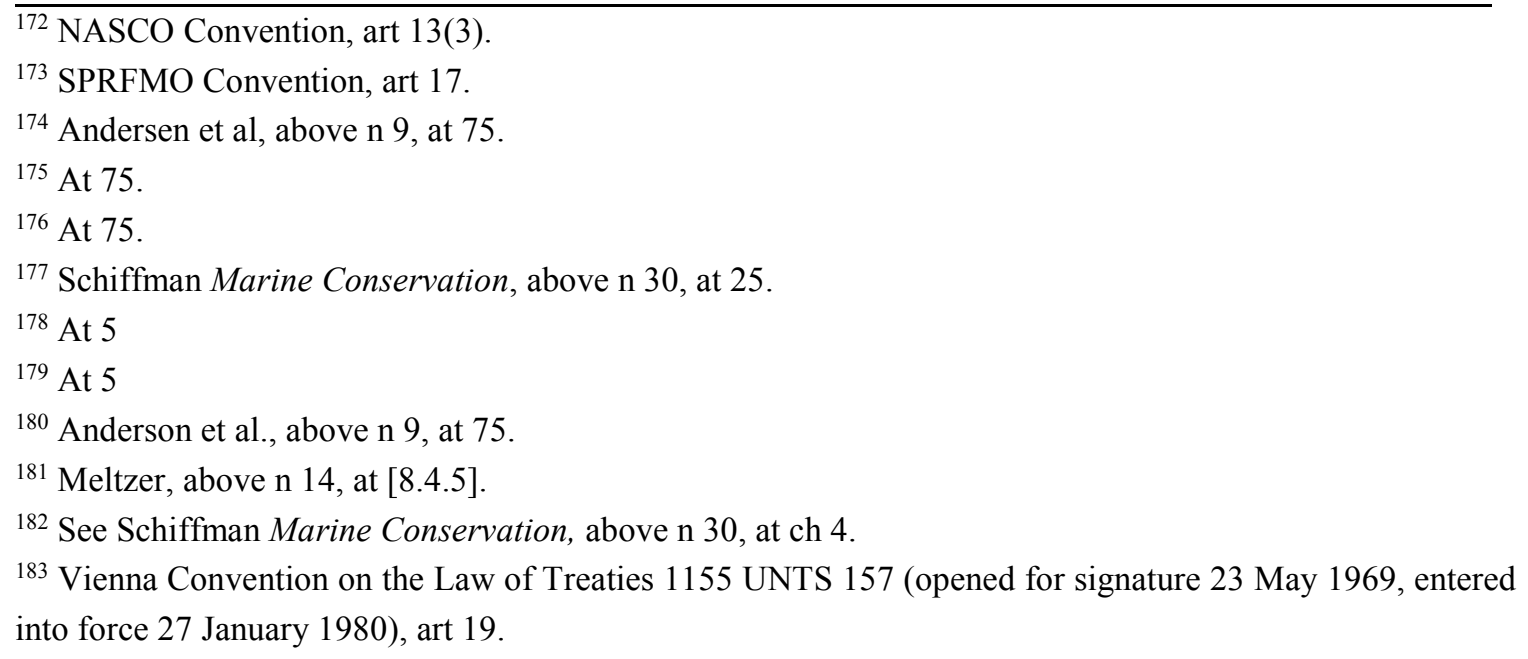


of objections should not frustrate the objectives of an RFMO's convention. ${ }^{184}$ Indeed, States are obliged to refrain from acts that would defeat the object and purpose of a treaty they are party to. ${ }^{185}$ Their use should also be constrained by the duty on States to co-operate in good faith with RFMOs and treaty partners, as well as obligations in the UNCLOS and FSA where States are parties to these treaties, or where these obligations represent international customary law. ${ }^{186}$ However, ensuring States conform to these obligations is easier said than done in practice. ${ }^{187}$

Despite the legal limits placed on objection procedures, their repeated use has damaged RFMO regimes in the past. The history of the North Atlantic Fisheries Organisation (NAFO) is a prime example of this. NAFO's decision-making contains an objection procedure with few prescribed limits on its use. ${ }^{188}$ States are able to opt-out of a decision without providing any justification or proposing alternative measures. ${ }^{189}$ Schiffman notes that between 1979 and 2005, NAFO members lodged 160 objections to 83 separate conservation measures. ${ }^{190}$ Cox et al. observed that objections were mainly related to TACs, quotas and effort regulations; in other words, the most critical decisions an RFMO is tasked with making. ${ }^{191}$ Russell notes that the "abuse of the procedure has been identified as one of the principal reasons for the failure of NAFO to fulfil its objectives". ${ }^{192}$

NAFO's objection procedure was not only widely used, but also became a source of conflict from the 1980s onwards. ${ }^{193}$ The European Commission consistently used the objection procedure between 1986 and 1992, thereby allowing it to set its own TAC. ${ }^{194}$ This often significantly exceeded the ones set by NAFO, and contributed to the deterioration of stocks under management. ${ }^{195}$ The consistent abuse of the objection

$\overline{184}$ Vienna Convention on the Law of Treaties, art 18; and Schiffman Marine Conservation, above $\mathrm{n}$ 30, at 172-181.

185 Vienna Convention on the Law of Treaties, art 18.

${ }^{186}$ Anderson et al., above n 9, at 75; See Meltzer, above above n 14, at 189.

187 Schiffman Marine Conservation, above n 30, at 198.

188 NAFO Convention, art XII.

189 Anthony Cox, Leonie Renwrantz and Ingrid Kelling Strengthening Regional Fisheries Management Organisations (Organisation for Economic Co-Operation and Development, 2009) at 94.

190 Schiffman Marine Conservation, above n 30, at 55.

${ }^{191}$ Cox et al., above n 189, at 101.

192 Dawn A. Russell and David L.Vanderswagg (ed.) Recasting Transboundary Fisheries Management Arrangements in Light of Sustainability Principles (Martinus Nijhoff Publishers, Leiden, 2010) at 246.

${ }^{193}$ Russell et al., above n 192, at 246.

194 Schiffman Marine Conservation, above n 30, at 57.

195 Schiffman Marine Conservation, above n 30, at 57; and Russell et al., above n 192, at 246. 
procedure prompted Canada to take expansive unilateral enforcement action in order to conserve cod fisheries. This led to a souring of relations between Canada and Europe, with Spain even taking Canada to the International Court of Justice. ${ }^{196}$ Altogether, this demonstrates that objections can not only impact on the conservation effect of management decisions, but can also undermine co-operation and decision acceptability within the RFMO.

As with consensus or unanimity based decision-making, it does not necessarily follow that objections will hinder the effectiveness of an RFMO. Schiffman states that the IOTC's objection procedure has been used infrequently, and Meltzer observes that CCAMLR's full objection procedure has never been activated. ${ }^{197}$ However, objection procedures evidently have the potential to compromise effective decision-making. They can undermine the conservation effect of a decision where unilateral measures are taken. Additionally, by reducing the acceptability of adopted measures to other RFMO members, their use can generate division and disputes that undermine co-operation. It is thus important that RFMOs design objection procedures that mitigate these risks, and ensure that "any post[]objection behaviour is consistent with other general obligations of state parties". ${ }^{198}$

\section{$V$ Reforming RFMO Decision-Making: Suggested Best Practice}

Thus far this paper has illustrated how problems involving two key components of RFMO decision-making processes can hamper effectiveness. Even before arriving at the problems of State compliance and enforcement, consensus-based decision-making and objection procedures can combine to produce a decision with limited conservation effect. That is, if a decision is made at all.

Any solutions to the problems confronting RFMO decision-making have to carefully balance the need to respect state sovereignty whilst ensuring robust and timely decisions are made. As Meltzer has put it, a "central tension characterizing international fisheries organizations is the need for balancing state sovereignty with the obligation to cooperate within an RFMO" ${ }^{199}$ On one hand, there is little the law of the sea can do to compel recalcitrant states to adopt more robust conservation and enforcement measures. Indeed, "without the will to agree, the details of the decision-making procedures may make little

\footnotetext{
196 Schiffman Marine Conservation, above n 30, at 58-62.

${ }^{197}$ Meltzer, above n 14, at [8.4.5].

${ }^{198}$ At 194.

${ }^{199}$ Meltzer, above n 14, at XXXIX.
} 
difference". ${ }^{200}$ On the other hand, the design of RFMO decision-making can help ensure meaningful decisions, that are consistent with the law of the sea, will be adopted. ${ }^{201}$

This section will identify RFMO measures that are seen as best practice solutions to the problems confronting objection procedures and consensus-based decision-making. However, in discharging their duty of co-operation through RFMOs, the FSA does not require States to apply a specific form of decision-making procedure. ${ }^{202}$ It only requires decision-making be "timely and effective". ${ }^{203}$ Therefore, this framework will be sourced from the recommendations of the Chatham House Panel as well as developments with RFMOs themselves that are most likely to achieve the criteria for effective decisionmaking. In turn, this advice on RFMO best practice will be used to help evaluate whether SPRFMO can serve as a model for other RFMOs.

\section{A Decision-Making: Requisite Support}

There is tension when it comes to defining best practice decision-adoption procedures. On one hand, unanimity or mandatory consensus-based decision-making may be the best way of ensuring support for a decision. ${ }^{204}$ Conversely, it is open to abuse and is thus arguably not the best process for achieving 'effective decisions'. Therefore, the challenge, as stated by McDorman,: ${ }^{205}$

is to encourage the "best" outcomes that enlist as many States as possible as supporters and, most importantly, engage the support of the States with the most interest in the outcomes.

In light of these potentially conflicting objectives, best practice is to find a balance between the benefits of consensus and decisiveness of majority voting.

\section{Aim for Consensus}

Firstly, a best practice RFMO should aim to encourage consensus. As was noted in the context of CCAMLR, the requirement for consensus brought: ${ }^{206}$

\footnotetext{
${ }^{200}$ Judith Swan Decision-Making in Regional Fisheries Bodies or Arrangements: The Evolving Role of RFBS and International Agreement on Decision-Making Processes (FAO, Fisheries Circular No. 995, 2004) at 9.

${ }^{201}$ Ceo et al., above $\mathrm{n} 142$, at 90.

${ }^{202}$ Henriksen et al., above n 48, at 204.

${ }^{203} \mathrm{FSA}$, art $10(\mathrm{j})$.

${ }^{204}$ Anderson et al., above $\mathrm{n} 9$, at 40-41.

${ }^{205}$ McDorman, above $\mathrm{n} 38$, at [12].

${ }^{206}$ Ceo et al., above n 142, at 68.
} 
a strong sense of cooperation and in most cases compromises had been reached on matters of difference. It has also helped to adopt a serious negotiating effort and to create a better climate for the respect and self-enforcement of decisions.

The fact consensus helps to build co-operation gives it the edge over majority-based voting methods. Voting may promote timeliness, but this has limited value if parties do not agree or if it creates divisiveness in the organisation. Consensus is also slightly more flexible than unanimity, as parties do not have to express a position in favour or against for a measure to pass. ${ }^{207}$ Therefore, as consensus promotes both co-operation and decision acceptability, and thereby better self-enforcement, it is a goal all RFMOs should explicitly aim for in their decision-making. ${ }^{208}$

\section{Consensus Should be Supported by Majority Voting}

Whilst the FAO may recommend consensus for "decisions possessing normative and regulatory effects", on balance, it is important that the process allows for decisions to be made where consensus cannot be reached. ${ }^{209}$ As has been discussed above, with a strict unanimity or consensus requirement, all it takes is for one member State to take issue with a decision and the whole process can grind to a halt. Hence the Chatham House Panel's blunt description of a unanimity or consensus requirement as "not best practice". 210 Therefore an RFMO's decision procedure should allow for a majority vote where consensus is not able to be achieved. This process can act as a form of "circuit breaker" if a decision is being blocked by a small minority of States. ${ }^{211}$

The main advantage of a vote based system is that "the issue is resolved at a specific point in time" and it allows a decision to be finally taken. ${ }^{212}$ No one member is able to derail the process. ${ }^{213}$ However, majority voting does come with downsides. It can create division amongst an RFMO's members as well as encourage the use of objection procedures. Moreover, a State that is bound by a decision to which it did not agree may be less likely to self-enforce that ruling. ${ }^{214}$ Another disadvantage may be discouraging States from

\footnotetext{
${ }^{207}$ Meltzer, above n 14, at [8.4.3].

${ }^{208}$ At [8.4.4.2].

${ }^{209}$ Ceo et al. above $n$ 142, at 69.

${ }^{210}$ Anderson et al., above $\mathrm{n} 9$, at 73.

211 At 40.

${ }^{212}$ Meltzer, above $n$ 14, at [8.4.3]

${ }^{213}$ Meltzer, above n 14, at [8.4.3]

${ }^{214}$ At [8.4.4.2]; and Pinto, above n 4, at 129.
} 
becoming members, particularly coastal states who feel they may be out-voted by distant water fishing states in an RFMO. ${ }^{215}$

The disadvantages of majority voting mean that the 'circuit-breaker' procedure should require more than a simple majority (that is 50 per cent plus one) to pass decisions. ${ }^{216}$ The experience of NAFO illustrates why. The NAFO Convention provides that all conservation and management decisions only require a simple majority to pass. ${ }^{217}$ This was combined with an objection process that allows States to easily opt-out of measures. ${ }^{218}$ Historically, it appears decisions failed to enlist the support of members and build co-operation. This led to widespread use of objection procedures, and an ineffective conservation regime. ${ }^{219}$ NAFO has consequently agreed to introduce consensus-based decision-making combined with a stricter objection process, however the amendment treaty has yet to enter into force. ${ }^{220}$ Furthermore, even if one took the objection procedure out of the simple majority equation, the concern is that conservation measures may simply be ignored by States. ${ }^{221}$ Joyner stated this would have occurred had CCAMLR used majority decision-making in its early years. ${ }^{22}$ Moreover, consensus-based decision-making was probably an important inducement for States to join the regime in the first place. ${ }^{223}$

In light of the problems with simply majority decision-making, the required majority should be significantly higher than a simple majority. This should certainly be the case for decisions around setting the TAC and the allocation of the TAC. This is because the "more State-sensitive a decision ... the more important is direct state consent". ${ }^{224}$ In fact, the WCPFC has a 'consensus list' that requires the most sensitive conservation and management measures to be made by consensus. ${ }^{225}$ This includes the setting of a TAC as well as fishing effort levels. ${ }^{226}$ All other measures are can be pass by a three-quarters

\footnotetext{
${ }^{215}$ Schiffman Marine Conservation, above n 30, at 50.

${ }^{216}$ Meltzer, above n 14, at 191.

${ }^{217}$ NAFO Convention, art XIV.

${ }^{218}$ Art XII.

${ }^{219}$ Schiffman Marine Conservation, above n 30, at 54-63.

${ }^{220}$ Amendment to the Convention on Future Multilateral Cooperation in the Northwest Atlantic Fisheries (adopted 28 September 2008, not yet in force), arts XIII-XIV; Cox et al., above n 189, at 108-109; and Russell et al., above n 192, at 253-254.

${ }^{221}$ Joyner, above n 144, at 125.

222 Joyner, above n 144, at 125; and Schiffman Marine Conservation, above n 30, at 154

${ }^{223}$ Seee Schiffman Marine Conservation, above n 30, at 153.

${ }^{224}$ McDorman, above $\mathrm{n} 38$, at [13].

${ }^{225}$ Henriksen et al, above n 48, at 207

${ }^{226}$ WCPFC Convention, art 10(4).
} 
majority. However, Henriksen et al. note the measures added to the 'consensus list' were obviously put there because they were contentious. "This is precisely why submitting them to decision-making by consensus may hamper the future effectiveness of the WCPFC". 227 Therefore, in line with the Chatham House Panel's recommendations, all substantive decisions should require a two-thirds majority for adoption, rising to three-quarters if the RFMO has more than 12 members. ${ }^{228}$ This ensures that an RFMO can still make decisions if they enjoy widespread support.

Additionally, it is important to underscore that disagreement should not automatically result in a majority vote. In fact, due to the benefits of consensus, this should ideally be the last course of action. The Chatham House Panel recommended that there should be a presiding officer who ensures there is no premature recourse to voting. ${ }^{229}$ Moreover, before a vote is called, the Panel noted that the use of a neutral conciliator can be a helpful way of helping guide parties to a consensus. ${ }^{230}$

\section{Alternative Solutions}

Realistically, there will continue to be RFMOs that require mandatory consensus for conservation and management decisions. For example, in smaller RFMOs such as CCSBT there may be little alterative to consensus based decision-making, unless there is a very liberal objection procedure. ${ }^{231}$ The Chatham House Panel therefore suggests that RFMOs with less than four members make decisions on the basis of consensus, but grant a disaffected member the right to have the decision reviewed by a panel if they do not object to the decision being made. ${ }^{232}$ This is to mitigate the veto problem. Another method that can be adopted, is allowing a conciliator to be appointed that can try and resolve any disputes. ${ }^{233}$ The Chatham House Panel stated this was often effective to preventing deadlock. ${ }^{234}$ However, the downside of this method is that a conciliator cannot compel agreement. A single State can still block the decision-making process.

If consensus is a bottom-line for an RFMO's members, the Convention's decision-making criteria can also work to ensure measures have a certain conservation effect. It can

\footnotetext{
${ }^{227}$ Henriksen et al., above n 48 at 205-206.

${ }^{228}$ Anderson et al., above n 9, at 124.

${ }^{229}$ At 75.

${ }^{230}$ At 75 .

231 See Schiffman Marine Conservation, above n 32, at 126.

${ }^{232}$ Anderson et al., above n 9, at 124.

233 Anderson et al., above $\mathrm{n} 9$, at 75.

${ }^{234}$ At 75.
} 
introduce minimum standards such as "harvest controls, precautionary reference points, and other science-based decision rules ... can serve as the lowest common denominator to ensure the sustainability of the stocks. These standards can act as a default position" if agreement cannot be reached. ${ }^{235}$ One example of this is in the CCBSP Convention. If parties cannot agree to a TAC, then the Convention prescribes the levels at which the TAC must be set at, depending on the biomass of Alaskan Pollock. ${ }^{236}$ This helps to ensure the continuity of the management regime even where deadlock exists.

Strict consensus or unanimity may also be necessary to satisfy coastal states that they will not be outvoted by distant water fishing states "that more aggressively pursue commercial stocks". ${ }^{237}$ This is evidently the case with the South-East Atlantic Fisheries Organisation (SEAFO) and the CCBSP. ${ }^{238}$ However, as with smaller RFMOs, there is still a strong case for provisions to mitigate the effect of a hold-out State on the decision-making process. Moreover, the use of chamber voting can help alleviate coastal State concerns. ${ }^{239}$ In the WCPFC substantive decisions must be taken not only by a three-quarters majority of member States, but a three-quarters majority of the 14 members of the Pacific Islands Forum Fisheries Agency. ${ }^{240}$ This forms the body of relevant coastal states. A system where there is overall majority voting, but a requirement for all coastal States to consent, would be arguably superior to strict consensus voting. However, a coastal State veto may risk discouraging distant water fishing States from participating.

\section{Summary}

Best practice is for RFMO decision-adoption procedures is to strike a balance by combining a consensus requirement with majority voting. This recognises that, whilst consensus is desirable for decision-acceptability and participation, it may not always be possible to achieve complete support for a decision. In order to avoid the impacts that vetoes and deadlocks can have on conservation-orientation and timeliness, a best practice RFMO should allow decisions to be adopted with a significant majority as a last resort. However, as will be discussed below, it is important to combine this with a robust objection procedure. This in order to accommodate dissenting views and to encourage RFMO membership and participation.

\footnotetext{
${ }^{235}$ Meltzer, above n 14, at 192-193.

${ }^{236}$ CCBSP, annex pt 1.

${ }^{237}$ Schiffman Marine Conservation, above n 32, at 49.

${ }^{238}$ At $49-50$.

${ }^{239}$ Anderson et al., above $\mathrm{n} 9$, at 75 .

${ }^{240}$ WCPFC Convention, art 20(2).
} 


\section{B Objection Procedures}

The main focus for improving objection procedures has been "efforts made to qualify RFMO objections procedures to ensure that the conservation regime for these stocks is not undermined by unilateral action" 241 This recognises the reality that objection procedures allow States to protect themselves against decisions they believe are adverse to their interests. ${ }^{242}$ Realistically, they are therefore needed for States to fully accept RFMOs. This is all the more so if an RFMO does not have a strict consensus or unanimity requirement, thereby removing the ability for a single State to veto a decision. Furthermore, Schiffman argues that: $:^{243}$

there is ample evidence ... to indicate that exemptive provisions are helpful, if not necessary to "widen the tent" of conservation and management organizations and accommodate a variety of interests within the regime. This includes the differing interests of coastal and distant water fishing states, developed and developing states, new entrants to a regime as well as traditional consumers of a resource

The challenge is therefore not to remove objections from decision-making procedures, but to ensure they are designed so that they promote, rather than undermine, effective conservation and management measures.

\section{The Middle Ground Approach:}

Both accepting the need for objection procedures whilst also ensuring they are not abused by States leads to what Pinto calls the "middle ground approach". 244 The elements of this approach arguably represent current best practice for RFMOs. ${ }^{245}$ The 'middle ground' includes a "combination of conditions for grounds of objection; restriction of objection procedures to a number of subjects within the convention, recourse to binding dispute resolution and settlement procedures; and the reversal of the burden on the objecting State". ${ }^{246}$ Other requirements that fit with this approach are a requirement for reasoned objections as well as an alternative unilateral programme that does not undermine the conservation regime. ${ }^{247}$

\footnotetext{
${ }^{241}$ Meltzer, above n 16, at [8.1]

242 Pinto, above n 4, at 129-130.

243 Schiffman Marine Conservation, above n 30, at 199.

244 Pinto, above $\mathrm{n} 4$, at v.

245 At 132.

246 Pinto, above n 4, at 132-133.

${ }^{247}$ Henriksen et al., above n 48, at 207-208.
} 
The example of a middle ground approach used by Pinto is the Western and Central Pacific Fisheries Organization (WCPFC). ${ }^{248}$ Whilst not an "explicit objection procedure", its process for reviewing decisions has several core elements common to newer objection procedures. ${ }^{249}$ Therefore it is still a worthy example of middle ground approach.

The WCPFC's decision-making process first aims to achieve consensus, but allows for questions of substance to be taken by a three-quarters majority where consensus is unachievable. ${ }^{250}$ Certain matters, such as the establishment of the TAC must always be decided by consensus. ${ }^{251}$ If a participant objects to a decision taken by consensus, then that objection is submitted to a conciliator to try and reconcile differences and achieve consensus on the decision. ${ }^{252}$ However, if a decision is made by a majority vote, those States who voted against or where absent have 30 days to initiate a panel process that will review the decision. ${ }^{253}$ There are only two available grounds for review. Firstly, the decision is inconsistent the WCPFC Convention, the UNCLOS or the FSA. Secondly, the decision unjustifiably discriminates in form or in fact against the member concerned. ${ }^{254}$

If the panel considers that the decision does not need to be modified or revoked, it becomes binding on all members. ${ }^{255}$ However, if it finds the decision needs to be modified or changed, the WCPFC Commission is required, at its next annual meeting, to modify the decision so that it conforms to the Panel's recommendations. ${ }^{256}$ It may also revoke the decision. ${ }^{257}$ A special meeting can also be called to do this. ${ }^{258}$

Schiffman contends that the combination of a review panel and conciliator not only protects the interests of member States, but also helps safeguard conservation objectives. ${ }^{259}$ However, for a middle ground approach the WCPFC is quite strict on 'objecting' States.

\footnotetext{
248 Pinto, above $n$, at 130-33.

${ }^{249}$ See Meltzer, above n 14, at [8.4.5.1]; and McDorman, above n , at [18].

${ }^{250}$ WCPFC Convention, art 20(1)-(2).

${ }^{251}$ Art 10(4).

${ }^{252}$ WCPFC Convention, art 20(4); and Pinto, above n 4, at 131.

${ }^{253}$ WCPFC Convention, art 20(6).

${ }^{254}$ Art 20(6).

${ }^{255}$ Art 20(8).

${ }^{256}$ WCPFC Convention, art 20(9).

${ }^{257}$ Art 20(9).

${ }^{258}$ Art 20(9).

${ }^{259}$ Schiffman Marine Conservation, above n 9, at 202.
} 
McDorman notes the grounds for review are very narrow. ${ }^{260}$ If they do not prove either non-compliance with international law or discrimination, the State is bound by the decision. This is unless the special meeting modifies the decision so the objecting State is no longer to subject to it. ${ }^{261}$ Whilst the procedure protects a decision's coherence and conservationorientation, it can undermine decision acceptability, particularly as the State would not have actually voted for the decision. Moreover, this could discourage membership of the RFMO which would weaken the potency of the decision-making regime. As such, strict objection procedures present risks to decision-making efficacy.

\section{Limited Grounds for Objection}

Whilst the WCPFC may present some concerns when measured against McDorman's criteria as well as the goal of wide participation, its core elements are largely consistent with the Chatham House Panel's advice on RFMO objection procedures. ${ }^{262}$ The first of these is that there should be limited grounds for entering an objection. ${ }^{263}$

The Chatham House Panel recommends that objections should be reasoned and based on the same two grounds as WCPFC review process: inconsistency with international law and unjustified discrimination. ${ }^{264}$ This acknowledges that there are legitimate reasons why a State may want to object to a decision. ${ }^{265}$ Additionally, by stating what these are, it narrows the scope of for States to abuse the procedure, and allows for the objection to be scrutinised

by other States. ${ }^{266}$ It guarantees States cannot legally object if the decision is consistent with international law and does not constitute unjustified discrimination against a State. ${ }^{267}$ States participation and acceptability is still encouraged as they are still afforded a degree of protection from decisions with which they disagree.

\section{Review Panels}

The Chatham House Panel also recommends that when an objection is submitted, a panel of independent experts "shall review the objection without delay and report its conclusions to the appropriate organ of the RFMO". ${ }^{268}$ If the panel endorses the decision, it should

\footnotetext{
${ }^{260}$ McDorman, above n 38, at [18].

261 At [18].

262 See Anderson et al, above n 9, at 124-125.

263 At 124.

${ }^{264}$ At 76.

265 At 76.

266 Schiffman Marine Conservation, above n 30, at 322.

${ }^{267}$ Meltzer, above n 14, at 194.

268 Anderson et al., above n 9, at 125.
} 
come into effect and be implemented by all members. ${ }^{269}$ If it upholds the objection, the RFMO should urgently reconsider the decision and make a new decision. Any objections to this should be "submitted to the RFMO"s procedures for the settlement of disputes". 270 It also suggests panels should have the power to establish interim measures. ${ }^{271}$

Review panels are arguably a critical part of decision-making best practice. They have become increasingly popular amongst RFMOs. ${ }^{272}$ "By submitting to a timely and fair dispute process, States give effect to their dual duties to cooperate and to conserve and cannot use the inability to agree as a reason for postponing or failing to take conservation and management action". ${ }^{273}$ Incorporating a review panel into the objection procedure also helps prevents disputes from escalating, which could further decelerate the decisionmaking process and thereby threaten conservation effect. Moreover, it provides a relatively quick method for assessing whether an objection is justified. ${ }^{274}$ This helps to overcome the problem of identifying whether a State's objection is consistent with the treaty regime or not. ${ }^{275}$ It is therefore important to integrate some form of review panel type process into the objection procedure.

\section{Interim and Alternative Measures:}

One aspect missing from WCPFO's procedures is an express requirement to adopt interim or alternative measures while the objection is being resolved. The Chatham House Panel recommends that the objecting State should not be able to take action that could compromise the sustainability of stocks or undermine the objection procedure itself. ${ }^{276}$ This reiterates calls by the 2006 Fish Stocks Review Conference that States should: ${ }^{277}$

Ensure that post opt-out behavior is constrained by rules to prevent opting out parties from undermining conservation, clear processes for dispute resolution, and a description of alternative measures that will be implemented in the interim.

\footnotetext{
269 Anderson et al., above n 9, at 125 .

270 At 125.

${ }^{271}$ At 125

272 Henriksen et al., above n 48, at 207-208.

${ }^{273}$ Meltzer, above n 14, at 210.

274 At 194.

${ }^{275}$ Cox et al., above n 189, at 101; and Meltzer, above n 14, at 194.

276 Anderson et al., above n 9, at 76 and 124.

277 Report of the Review Conference on the Agreement for the Implementation of the United Nations Convention on the Law of the Sea of 10 December 1982 relating to the Conservation and Management of Straddling Fish Stocks and High Migratory Fish Stocks A/CONF.210/2006/16 (2006) at 35.
} 
Interim and alternative measures are therefore an important method for preventing States from taking damaging unilateral action, thereby helping to preserve the conservation-effect of the original decision. ${ }^{278}$ A requirement for an objecting State to propose and implement alternative measures, therefore, arguably represents best practice.

Disappointingly, as Table Two illustrates (above) few RFMO conventions oblige States to develop such measures. With SEAFO, one of the more modern RFMOS, they are at least a possibility. ${ }^{279}$ If a member objects to a decision then it is prima-facie non-binding in respect of that member. ${ }^{280}$ They do have to provide reasons and, "where appropriate", proposals for alternative measures that it will implement. ${ }^{281}$ However, if any member requires a meeting in response to the objection, then one is held to review the measure. ${ }^{282}$ If this occurs any SEAFO member can then request the establishment of an ad hoc expert panel to make recommendations on interim measures. ${ }^{283}$ If all non-objecting members agree that the long-term sustainability of relevant fish stocks would be undermined in absence of interim measures, the expert panel's recommendations become binding on the objecting State. ${ }^{284}$

With SEAFO, there are several hoops to jump through before interim measures can become binding on an objecting State. However, its process at least requires that State to consider implementing alternative measures. Moreover, the possibility of binding interim measures provides a degree security that the conservation effect of a decision will not be undermined if the objection threatens the long-term sustainability of a fish stock. ${ }^{285}$

\section{Alternative Solutions}

Other RFMOs have also developed milder methods for mitigating the negative effects of objection procedures. In the International Commission for the Conservation of Antarctic Tunas (ICCAT), an objection by less than one quarter of its members has no effect unless they reaffirm that objection within 60 days. ${ }^{286}$ The requirement for reaffirmation "indicates

\footnotetext{
${ }^{278}$ Meltzer, above n 14, at 194.

${ }^{279}$ McDorman, above n 38, at [16]-[17].

280 SEAFO Convention, art 23(c).

${ }^{281}$ Art 23(d).

$282 \operatorname{Art} 23(\mathrm{f})$.

283 Art 23(g).

${ }^{284}$ Art 23(g).

${ }^{285}$ Meltzer, above n 14, at 194.

${ }^{286}$ ICCAT Treaty, art VIII(3).
} 
a degree of added pressure on those states choosing to avail themselves of the objection procedure when they are in a relatively small minority". ${ }^{287}$ It also has effect of discouraging "other states from immediately filing additional objections". 288 An even simpler requirement, is requiring a State to provide written reasons for an objection and a description of any alternative measures it will take instead. ${ }^{289}$ This is used by SEAFO as the first stage in its review process, but even on its own it arguably "forces the State to exercise a much greater degree of care" before they use an exemption. ${ }^{290}$

Another innovation proposed by Schiffman is to require an RFMO's scientific committee to report on the environmental impact of an objection within a prescribed time period. ${ }^{291}$ This would be where the exemption contemplates greater fish consumption. ${ }^{292} \mathrm{He}$ contends that this would expose those States intending to unilaterally object to greater scrutiny and possible criticism. ${ }^{293}$ This would, as with re-affirmation, put further pressure on States to refrain from using the objection procedure. There is, however, the risk the scientific committee could become politicised, or would be unwilling to make clear-cut decisions in light of scientific uncertainty. ${ }^{294}$

\section{Summary}

Overall, there are a variety of processes available to an RFMO to help control the use and effect of objections. A best practice approach combines limited grounds for objection, a requirement that those grounds be justified before a review panel, and measures to ensure the conservation effect of a decision cannot be undermined. This strikes a balance between preserving the conservation effect of a decision, encouraging State membership, ensuring the objection is resolved in a timely manner, and preserving the acceptability of the decision to all parties.

\footnotetext{
${ }^{287}$ Schiffman Marine Conservation, above n 30, at 66.

288 At 66.

289 SEAFO Convention, art 23(1)(d)

290 Schiffman Marine Conservation, above n 30, at 201.

291 At 210-211.

292 At 210.

293 At 211.

${ }^{294}$ At 211.
} 


\section{SPRFMO: A Model for RFMO Decision-Making?}

One of the disconcerting conclusions of the Cullis-Suzuki and Pauly study was that "the effect of RFMO management on the stocks they control has, so far, been negligible". ${ }^{295}$ As RFMOs are the sole institutions with the power to make multilateral conservation and management measures for high seas stocks, it is highly important that solutions be found. ${ }^{296}$ From the perspective of high seas fish stock sustainability, the consequences of maintaining the status quo are simply unacceptable.

SPRFMO incorporates new processes that 'raise the bar' for RFMO decision-making, thereby offering a possible solution to problems affecting other RFMO decision-making processes. ${ }^{297}$ Indeed, an evaluation of its decision-making processes will show that it does meet RFMO best practice, incorporating many of the elements identified as necessary for effective decision-making. Importantly, SPRFMO not only meets the normative framework for effective decision-making developed in this paper; its decision-making procedures have also operated successfully in practice. The organisation has recently had to contend with a major dispute with a significant member State. This has put its cutting edge objection procedure to the test. ${ }^{298}$ This challenge has shown some short-comings with SPRFMO, but nonetheless shows the promise of its decision-making processes for other RFMOs.

\section{A SPFMO Background}

Established by the 2009 Convention on the Conservation and Management of High Seas Fishery Resources in the South Pacific Ocean, SPRFMO came into formal operation in 2012 and is one of the world's newest regional fisheries body. ${ }^{299}$ Its enormous area of responsibility includes the high seas stretching from the South-West of Australia to the western side of South America. ${ }^{300}$ It has the competence to make conservation and management measures for both straddling and highly migratory stocks, as well as discrete

\footnotetext{
${ }^{295}$ Cullis-Suzuki and Pauly "Failing the High Seas", above n 7, at 1041.

${ }^{296}$ At 1041.

${ }^{297}$ Schiffman “The South Pacific Regional Fisheries Management Organization”, above $n$ at 16, at 215-216; Schiffman "Fisheries Management", above n 32, at 118; and Mossop, above n 99, at 339.

${ }^{298}$ Mansfield, above n 16.

${ }^{299}$ SPRFMO Information Paper for the Review Panel (SPRFMO, June 2013) at 4-5.

${ }^{300}$ SRRFMO Convention, art 5.
} 
high seas fish stocks. ${ }^{301}$ SPRFMO currently has 13 members, ${ }^{302}$ as well as six co-operating non-contracting parties. ${ }^{303}$ Article two of the Convention gives its objective as: ${ }^{304}$

through the application of the precautionary approach and an ecosystem approach to fisheries management, to ensure the long-term conservation and sustainable use of fishery resources and, in so doing, to safeguard the marine ecosystems in which those resources occur.

Negotiations towards the SPRFMO Convention began in 2006 at the initiative of Australia, New Zealand and Chile. The aim was to address a regulatory gap for several fish stocks in the high seas of the South Pacific. ${ }^{305}$ The two fish stocks of primary concern are the straddling stock of Chilean jack mackerel (Jack mackerel), and the discrete high seas stock of orange roughy. Both of these fish stocks present major challenges to SPRFMO. ${ }^{306}$ Jack mackerel stocks have declined rapidly in recent decades, whereas orange roughy stocks present their own unique issues. ${ }^{307}$ Not only is it particularly vulnerable to overfishing, as a slow growing and long living species, it is also harvested using bottom trawling. This practice is considered to be particularly damaging to the environment, with uncertainty over its long-term impacts on the deep ocean ecosystem. ${ }^{308}$

As there was a significant period of time from the commencement of negotiations, to the entry into force of the SPRFMO Convention, the negotiating parties adopted voluntary and interim conservation and management measures from 2007 onwards. ${ }^{309}$ This was both in an effort to control bottom trawling and to halt the rapid of decline of jack mackerel

301 SPRFMO Convention, arts 1(f) and 8; and Yoshinobu Takei Filling Regulatory Gaps in High Seas Fisheries (Martinus Nijhoff Publishers, Boston, 2013) at 216-217.

302 SPRFMO "Status of the Convention" (2014) SPRFMO <www.sprfmo.int>.

${ }^{303}$ SPRFMO "Participation" (2014) SPRFMO < www.sprfmo.int>.

${ }^{304}$ SPRFMO Convention, art 2.

305 Takei, above n 301, at 210.

306 United Nations Making the Fish Stocks Agreement Work (United Nations Department of Public Information, DPI/2556 F, May 2010) at 1.

${ }^{307}$ Mar Cabra and Mort Rosenblum "Where have all the fish gone?" The Sydney Morning Herald (online ed, Sydney, 30 January 2012).

${ }^{308}$ Schiffman "The South Pacific Regional Management Organization", above n 16, at 211; and Schiffman "The Evolution of Fisheries Management", above n 32, at 184-185.

${ }^{309}$ Takei, above n 301, at 211; SPRFMO Information Paper, above n 299, at 7-8. 
stocks. ${ }^{310}$ However, arguably the delay around installing these interim measures was SPRFMO's first set-back. By beginning negotiations towards an RFMO to regulate jack mackerel, "a scramble bordering on the edge of madness" was triggered. ${ }^{311}$ In order to improve their claims for future allocations of jack mackerel by SPRFMO, States increased fishing for the stock with new participants entering the fishery. ${ }^{312}$

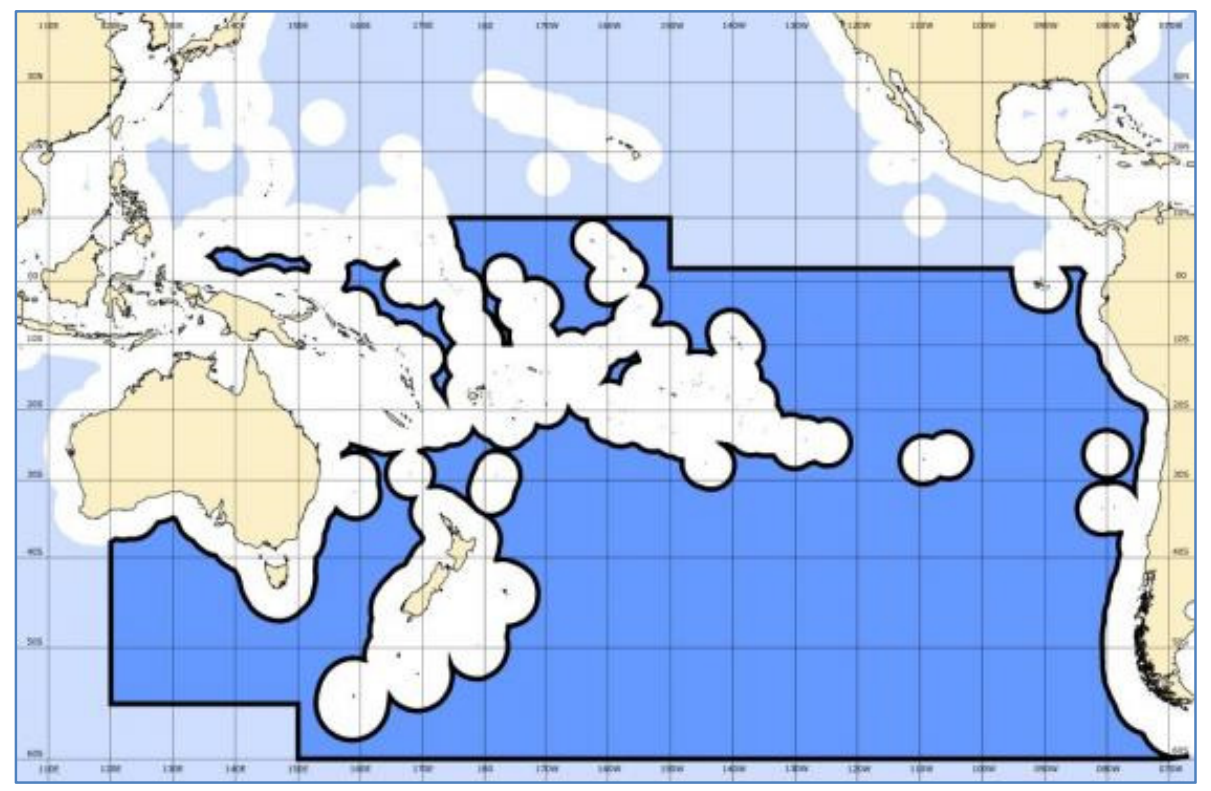

Figure Three: SPRFMO Convention Area (Source: SPRFMO www.southpacificrfmo.org)

\section{B Decision-Making Rules}

Perversely, as a result of the SPRFMO negotiations, a fish stock already under pressure, became more vulnerable to collapse. Arguably, it is therefore even more imperative that the SRPFMO succeed in turning around the fortunes of jack mackerel and orange roughy fish stocks. It is fortunate, therefore, that the decision-making rules in the SPRFMO Convention perform well against the best practice framework developed in this paper.

\footnotetext{
310 Review Panel Established under the Convention on the Conservation and Management of High Seas Fisheries Resources in the South Pacific Ocean [Review Panel] (Fisheries Management Dispute) PCA (5 July 2013) at [20]-[21]; and Takei, above n 301, at 211-214.

${ }^{311}$ Robert Deuchars "Governmentality and Risk: Managing 'Ocean Space”" (LLM Research Paper, Victoria University of Wellington 2013) at 22.

312 Mansfield, above n 16; SRPFMO "Information Paper" at [11]; and Cabra and Rosenblum, above n 307.
} 


\section{Requisite Majority}

SPRFMO's governing convention first provides that as a general rule substantive decisions shall be taken by consensus. ${ }^{313}$ In contrast, procedural decisions are taken by a simple majority. As is typical with RFMOs, consensus is defined as the absence of a formal objection at the time the decision was made. ${ }^{314}$ However, Article 16 allows for the requirement for consensus to be avoided: ${ }^{315}$

If the Chairperson considers that all efforts to reach a decision by consensus have been exhausted:

(b) decisions on questions of substance shall be taken by a three fourths majority of members of the commission casting affirmative or negative votes.

Whether a decision is one of substance is in itself a decision of substance. Decisions on questions of substance then become binding on all SPRFMO participants 90 days after the decision is transmitted to SPRFMO participants by the head of its Secretariat. ${ }^{316}$ Therefore consensus is not necessary for the adoption of conservation and management measures by the SPRFMO Commission. ${ }^{317}$

\section{Objection Procedure}

SPRFMO members have the right to object to the Commission's substantive decisions. The only exception to this is where a decision is adopted on an emergency basis. In that case the decision is binding on all members, subject to dispute resolution procedures, and no objections are allowed. ${ }^{318}$

The design of the objection procedure puts a number of limits on its use. Firstly, an objection must be lodged within 60 days of the decision being transmitted to SPRFMO members. ${ }^{319}$ Then, at the same time as the objection is presented, Article 17 states that the objecting state must: ${ }^{320}$

313 SPRFMO Convention, art 16(1).

${ }^{314}$ Art 16(1).

${ }^{315}$ Art 16(2).

${ }^{316}$ Art 17(1).

${ }^{317}$ Mossop, above n 99, at 337.

${ }^{318}$ SPRMO Convention art 20(5).

${ }^{319}$ Art 17(2)(a).

${ }^{320}$ Art 17(2)(b). 
(i) specify in detail the grounds for its objection;

(ii) adopt alternative measures that are equivalent in effect to the decision to which it has objected and have the same date of application; and

(iii) advise the Executive Secretary of the terms of such alternative measures.

Moreover, there are only two grounds for objection. These are either that the decision unjustifiably discriminates in form or in fact against the member, or that the decision is inconsistent with the provisions of the SPRFMO Convention or other relevant international law, as reflected in the UNCLOS and the FSA. ${ }^{321}$

Additionally, an objection triggers an elaborate process for reviewing the substantive decision. Firstly, a Review Panel must be established within 30 days of the 60 day objection period ending. ${ }^{322}$ This Panel consists of three members selected from the FAO's list of fisheries experts. ${ }^{323}$ Then within 45 days of its establishment, the Panel must report on: ${ }^{324}$

whether the grounds specified for the objection presented by the member or members of the Commission are justified and whether the alternative measures adopted are equivalent in effect to the decision to which objection has been presented.

The Panel thus has two key decisions to make. Exactly how it concludes on these two decisions can prompt a variety of different outcomes for the objecting State, and SPRFMO more broadly. Possibly the simplest outcome is if the Panel finds that the objector has been the subject of unjustified discrimination and, additionally, that the objecting State's alternative measures are equivalent in effect to the original decision. In that case, the objector's alternate measures become binding on the objector in substitution for the original decision. ${ }^{325}$

${ }^{321}$ SPRMO Convention, Art 17(2)(c).

${ }^{322}$ Art 17(5)(a).

${ }^{323}$ Annex II para 1(a).

${ }^{324} \operatorname{Art~17(5)(e)~}$

${ }^{325}$ Annex II para (10)(a). 
Matters become more complicated if the Panel finds discrimination against the objector, but also determines that the alternative members are not equivalent or need "specific modifications" to achieve equivalence: ${ }^{326}$

a) If the Panel recommends "specific modifications", the objector has 60 days to modify its measures or institute dispute resolution proceedings. Dispute resolution proceedings would ultimately entail compulsory dispute resolution under the Part XV of the Law of the Sea Convention, if it is not resolved by other processes. ${ }^{327}$ However, if it does choose to modify its measures, they become binding on the objector in place of the contested decision.

b) If the Panel finds the objector's alternative measures are not equivalent in effect to the substantive decision, the objector must either adopt the Panel's recommended alternative measures within 60 days or institute dispute settlement proceedings. ${ }^{328}$ If the recommended alternative measures are adopted, these become binding on the objector in substitution for the original decision. ${ }^{329}$

In both cases, the objector does has the right to also request an Extraordinary Meeting of the SPRFMO Commission. ${ }^{330}$ This must be done within 30 days the Panel's decision, and must be convened within 45 days of the request. ${ }^{331}$ The Extraordinary Meeting can confirm or modify the recommendations of the Review Panel, or it can even replace the substantive decision with a new or modified decision that will become binding on all commission members in accordance with the Convention's decision-making rules. ${ }^{332}$

An Extraordinary Meeting is automatic if the Panel finds the substantive decision is inconsistent with international law. ${ }^{333}$ The meeting must be held 45 days after the Panel's decision, and it may decide to revoke, modify or confirm the contested decision. ${ }^{334}$ The

\footnotetext{
326 See SPRMO Convention, Annex II para 10(b)-(c).

${ }^{327}$ Annex II para 10(c) and art 34; FSA, art 30; and UNCLOS, art 286.

328 Annex II para 10(c).

${ }^{329}$ Annex II para $10(\mathrm{c})$.

${ }^{330}$ Annex II para 10(d).

331 Annex II para 10(d).

332 Annex II para 10(e).

333 Annex II para 10(f).

334 Annex II para 10(g).
} 
objector than has another 45 days to implement the decision or institute the dispute resolution process provided for in the Convention. ${ }^{335}$

Finally, the Panel could find that a decision neither discriminated against the objector nor is it inconsistent with international law. In this situation the objector has 45 days to either implement the decision or institute binding dispute resolution proceedings under the Convention. ${ }^{336}$ However, if the Panel determines that the objector's alternative measures are equivalent in effect to the substantive measure, "the alternative measures shall be binding on the objecting member or members of the Commission in substitution for the decision pending confirmation of their acceptance by the Commission at its next meeting". 337

Overall, with SPRFMO, not only can substantive decisions be taken otherwise than by consensus, but an objecting State is not permitted to completely ignore the decision. It must still implement equivalent measures. ${ }^{338}$ This significantly limits the scope for an objection to impact on the conservation effect of a decision.

\section{Preliminary Evaluation}

SPRFMO's decision-making approach has been described by Mossop as "groundbreaking." ${ }^{339}$ Schiffman describes the "attempt to subject objections to a form of multilateral review" as "innovative" and part of a broader trend with newer RFMOs to reduce the negative impact of objections on RFMO efficacy. ${ }^{340}$ Moreover, SPRFMO's decision-making process is in line with the best practice framework developed earlier in this paper. Thus, on paper, SPRFMO constitutes a model for RFMO decision-making best practice.

Firstly, SPRFMO combines consensus-based decision-making with majority voting as a fall-back option. As SPRFMO has more than 12 members, it conforms to the suggested best practice for substantive RFMO decision-making. ${ }^{341}$ Any concerns that the absence of strict consensus for decision adoption might dissuade States from joining should be tempered by the fact most of the key States are already either members of SPRFMO or are

\footnotetext{
335 Annex II para 10(h).

336 Annex II para 10(i).

337 Annex II para 10(j).

${ }^{338}$ Mossop, above $\mathrm{n} 99$, at 338.

339 At 338.

340 Schiffman “The South Pacific Regional Fisheries Management Organization”, above n 16, at 212;

${ }^{341}$ Anderson et al., above n 9, at 124.
} 
cooperating parties. One aspect of suggested best practice missing from the Convention is the use of a conciliator where consensus cannot be achieved. However, the Convention does make it clear that putting a decision to a majority vote is a matter of last resort. ${ }^{342}$ Indeed, requiring one to be used every time there is deadlock might just further delay the decision-making process. Overall, SPRFMO's decision-adoption approach is consistent with best practice.

SPRFMO's objection procedure also has many of the key elements identified as best practice in this area. Firstly, there are limited grounds for objection. Secondly, alternative measures that do not undermine the conservation measure in question must be adopted by the objecting state. Finally, a review panel is automatically formed to rule on the legitimacy of the objection and the compatibility of the alternative measures. ${ }^{343}$

The objection process provides for States to avoid being bound by decisions they believe are inconsistent with international law or constitute unjustified discrimination. These are legitimate grounds for using an objection and should therefore encourage State participation and decision acceptability whilst limiting the scope for the procedure to be abused. Moreover, the requirement alternative measures be implemented helps to preserve the effect of the original decision, whilst also giving the objecting State flexibility to establish their own unilateral measures, as long as they are equivalent in effect. Moreover, the Review Panel ensures that the legitimacy of every objection and the compatibility of the objecting State's alternative measures are subject to third-party scrutiny. This will hopefully discourage States from objecting unless they have genuine grounds for doing so. ${ }^{344}$ Altogether this will help to preserve the conservation effect of decisions, as well as the consistency of objections with the object and purpose of the SPRFMO Convention.

One omission from the SPRFMO Convention is Schiffman's suggestion that the Scientific Committee should analyse the conservation impact of an objection. ${ }^{345}$ This is of particular interest as the Convention requires an objecting State to adopt measures that are of equivalent effect to the original decision. ${ }^{346}$ As there will be a Review Panel assessing the equivalence of the alternative measures, it may be of assistance if there was advice from the Scientific Committee on the objection's conservation impacts. However, considering

342 SPRFMO Convention, art 16(2).

${ }^{343}$ Anderson et al, above n 9, at 124-125.

${ }^{344}$ Schiffman Marine Conservation, above n 30, at 201-202.

${ }^{345}$ At 211.

${ }^{346}$ SPRFMO Convention, art 17(2)(b)(ii). 
the already tight timeframes to which a review panel has to operate, this would likely further slowdown the process and increase costs.

Mossop has noted that SPRFMO's decision-making processes "appear rather complicated, and have the potential to delay the proceedings of the Commission" if used regularly. ${ }^{347}$ Repeated use of the objection process would also be costly, especially for the objecting member who has to bear 70 per cent of expenses associated with the Review Panel. ${ }^{348}$ One possibility is that these factors could dissuade members from objecting. ${ }^{349}$ However, "another possibility is that the parties will become enmeshed in lengthy disputes". ${ }^{350}$ Whilst there are clear time frames in place, there is the possibility of an objector going through practically the whole Panel process, then deciding to opt for binding dispute resolution procedures. Binding dispute resolution would still produce a final outcome, but would add even more time and cost to the process. One therefore hopes the use of this procedure remains the exception, rather than then norm. Otherwise the impacts on timeliness and member co-operation will be detrimental to the effectiveness of the process.

The risks associated with SPRFMO's objection procedure are arguably the cost of ensuring decision acceptability in an RFMO where decisions can be taken without consensus. Moreover, in light of the already strict conditions placed on objections, it would have arguably been overly burdensome for the negotiating parties to circumscribe the objection procedure further. ${ }^{351}$ Therefore SPRFMO has struck a reasonable compromise between decision acceptability, timeliness and conservation orientation. It also incorporates most of the elements identified as decision making best practice. Altogether this means that, on paper, SPRFMO certainly provides a model for effective RFMO decision-making. Indeed, in many respects, it reads like the incarnation of the Chatham House Panel's model RFMO.

SPRFMO's on paper assessment is further boosted by other aspects of its decision-making rules. It incorporates clear, modern criteria and principles for adopting conservation and management measures. ${ }^{352}$ Interestingly, these criteria include a minimum standard for decision-making. Article 4(3) provides that its initial decisions shall take account of and

\footnotetext{
${ }^{347}$ Mossop, above n 99, at 338.

348 SPRFMO Convention, annex II para 7(a).

${ }^{349}$ Mossop, above n 99, at 338.

${ }^{350}$ At 338

${ }^{351}$ Meltzer, above n 14, at 194.

${ }^{352}$ Mossop, above n 99, at 336; Schiffman “The Evolution of Fisheries Management", above n 32, at 183183; SPRFMO Convention, arts 3 and 20-22.
} 
not undermine the effectiveness of conservation and management measures established by relevant coastal states and the SPRFMO members. ${ }^{353}$ Whilst not a default position that can operate where the requisite majority cannot be reached, it does institutionalise a benchmark which all SPRFMO parties are obliged to account for in making decisions. ${ }^{354}$ This should, initially at least, help protect the conservation effect of SPRFMO's decisions.

The SPRFMO Convention also provides that conservation and management measures should be compatible between jurisdictions, ${ }^{355}$ and even permits the organisations to make measures for areas within national jurisdiction with the consent of the relevant State. ${ }^{356}$ Moreover, Article 18 requires the SPRFMO Commission to promote transparency in its decision-making processes. ${ }^{357}$ It states representatives from non-Contracting States, International Organisations and NGOs should be able to observe Commission meetings and have access to relevant information. ${ }^{358}$ This should allow SPRFMO's members to be held accountable for any poor decisions. Altogether, when these elements are combined with the SPRFMO's decision-making process, this should help ensure its Commission makes effective decisions. Of course, whether this will ultimately be the case in practice is dependent on the political will of its members. ${ }^{359}$

\section{Case Study: SPRFMO in Light of the Russia Objection}

SPRFMO performs well when its decision-making rules are assessed against this paper's theoretical RFMO best practice framework. However, only two years into its formal existence, it is too early to assess SPRFMO's effectiveness in achieving its objective of long-term fish stock sustainability. Yet, within months of the SPRFMO Convention entering into force, its decision-making procedures have had to overcome a significant hurdle. In April 2013 Russia objected to the first set of conservation and management measures adopted by SPRFMO. ${ }^{360}$ As a result SPRFMO's review panel process was triggered. The outcomes of this dispute provide an opportunity to comment on SPRFMO

\footnotetext{
${ }^{353}$ SPRFMO Convention, art 4(3).

${ }^{354}$ Meltzer, above $\mathrm{n} 14$, at 197-198.

${ }^{355}$ SPRFMO Convention, art 4.

${ }^{356}$ Art 20.

${ }^{357}$ Schiffman "The South Pacific Regional Fisheries Management Organization", above n 16, at 212; and SRPFMO Convention, art 18(1).

${ }^{358}$ SPRFMO Convention, art 18(2)-(4).

${ }^{359}$ Mossop, above n 99, at 339.

${ }^{360}$ Russian Federation Federal Agency for Fisheries "Letter of Objection to Conservation and Management Measure 1.01" (19 April 2013) South Pacific Regional Fisheries Management Organisation $<$ www.southpacificrfmo.org $>$.
} 
and its "ground breaking" decision-making process. ${ }^{361}$ This will conclude that this process has ultimately strengthened the organisation, demonstrating that its unique decisionmaking and objection procedures can operate successfully. This further reinforces the contention that SPRFMO can act as a model for RFMO reform.

\section{Factual Background:}

On 1 February 2013, the first meeting of the SPRFMO Commission adopted Conservation and Management Measure 1.01 (CMM 1.01). ${ }^{362}$ CMM 1.01 set the 2013 TAC of jack mackerel. It followed a series of annual jack mackerel interim conservation measures aimed at halting the dramatic decline of this fish stock. ${ }^{363}$ The TAC was set at 360,000 tonnes for both the SPRFMO Convention area and fisheries under Chilean jurisdiction. ${ }^{364}$ None of the TAC was allocated to Russia. ${ }^{365}$

The Working Group that drafted CMM 1.01 decided that the 2013 TAC for jack mackerel should be allocated on the basis of each party's share of the 2010 jack mackerel catch. ${ }^{366}$ The data supplied to the Working Group did not contain the 2010 jack mackerel catch information supplied by Russia to the then SPRFMO Interim Secretariat. ${ }^{367}$ Russia therefore received a zero allocation of the 2013 TAC.

\footnotetext{
${ }^{361}$ Mansfield, above n 16.

362 Review Panel, above n 310, at [48]-[49]

${ }^{363}$ Mansfield, above n 15, 361.

${ }^{364}$ Review Panel, above n 310, at 13.

365 At [49].

366 Review Panel, above n 310, at [50].

367 At [46].
} 
Table 2: Tonnages in 2013 fishery as referred to in paragraph $6^{4}$

\begin{tabular}{|l|l|}
\hline Members / CNCP & Tonnage \\
\hline Belize & 1,145 \\
\hline Chile & 237,551 \\
\hline China & 32,507 \\
\hline European Union & 34,496 \\
\hline Faroe Islands & 5,950 \\
\hline Korea & 4,182 \\
\hline Peru & 20,707 \\
\hline Vanuatu & 23,462 \\
\hline Total & 360,000 \\
\hline
\end{tabular}

Footnote 4 to Table 2: The Russian Federation notified the Commission that it considers it had a legitimate right to a share in the fishery notwithstanding the situation referred to in footnote 3 and asserts its right to participate in the fishery in 2013 in a proportion calculated by a reference to the fishing activities it reported to the Executive Secretary in 2010.

Figure Three: Jack Mackerel Allocation in CMM 1.01 (Source: SPRFMO Www.southpacificrfmo.org)

The cause of Russia's exclusion from the official 2010 SPRFMO catch data was a dispute between Russia and the Interim Secretariat over a vessel named the Lafayette. In 2007, due to declining jack mackerel stocks, the parties negotiating the SPRFMO Convention agreed to report catch data to an Interim Secretariat amongst other interim conservation and management measures. ${ }^{368}$ In 2009 Russia advised that the Lafayette was fishing in the Convention area, and data was reported accordingly. ${ }^{369}$ However, in 2010, 2011 and 2012 the Interim Secretariat was provided with information that the Lafayette was not capable of fishing, and was a processing vessel. ${ }^{370}$ Moreover, the reported catch for the Lafayette in 2010 was 41,315 tonnes, with Peru claiming 31,275 tonnes had been transhipped from its vessels to the Lafayette. ${ }^{371}$

\footnotetext{
${ }^{368}$ Review Panel, above n 310, at [18]-[19].

369 At [27].

370 At 8-10.

${ }^{371}$ At [38]-[39].
} 
The situation with the Lafayette caused several SPRFMO members to voice concerns over double counting of the catch data. ${ }^{372}$ As a result of these concerns, the Interim Secretariat excluded Russia's catch from the Lafayette from their 2010 total catch data. This was "pending receipt of operational fishing information". ${ }^{373}$ Unfortunately for Russia, it had only supplied aggregated annual catch data in 2010 in respect of the Lafayette. The meant it now had a total jack mackerel catch for 2010 of zero in SPRFMO's official data. ${ }^{374}$

\section{Russia's Objection}

Although this is not made explicit in the decision or Review Panel documents, CMM 1.01 appears to have been adopted by consensus. ${ }^{375}$ However, in response Russia decided to make use of the objection procedure, filing an objection within 60 days of being notified of the decision by the SPRFMO Commission. ${ }^{376}$ As a result, a Review Panel was then formed in in May, 2013. ${ }^{377}$ Russia's grounds for objection were that the CMM 1.01 allocation decision both unjustifiably discriminated against Russia in form or fact, and that the decision was inconsistent with the SPRFMO Convention. ${ }^{378}$ Its alternative equivalent measures were to allocate itself a share of the 2013 jack mackerel TAC equal to its 2010 share of the catch. ${ }^{379}$

Several SPRFMO members submitted against Russia. They argued that SPRFMO was justified in excluding it from the 2010 data and that the decision was consistent with international law. ${ }^{380}$ Moreover, New Zealand expressed concerns that Russia's alternative measures were not equivalent in effect to CM 1.01 and that Russia's measures could undermine the already allocated TAC. ${ }^{381}$

\footnotetext{
372 Review Panel, above n 310, at [40].

${ }^{373}$ At [46].

${ }^{374}$ At [46].

${ }^{375}$ See SPRFMO Commission Conservation and Management Measure for Trachurus Murphyi (SPRFMO, CMM 1.01, 2013).

${ }^{376}$ Russian Federation Federal Agency for Fisheries, above n 360.

377 South Pacific Regional Fisheries Management Organisation "Establishment of Review Panel" (21 May 2013) South Pacific Regional Fisheries Management Organisation <www.southpacificrfmo.org>.

${ }^{378}$ Review Panel, above n 310, at [53].

${ }^{379}$ At [53].

380 At 16-20.

${ }^{381}$ New Zealand Ministry of Foreign Affairs and Trade "Memorandum of New Zealand to the Review Panel" (21 June 2013) South Pacific Regional Fisheries Management Organisation <www.southpacificrfmo.org> at [18]-[19].
} 


\section{The Panel's Decision}

This panel reported its findings on 5 July 2013, just within the 45 day timeframe set by the Convention. ${ }^{382}$ It concluded that Russia had been unjustifiably discriminated against in the Commission's allocation decision. ${ }^{383}$ The Panel found that the failure to allocate Russia any of the TAC was unintentional. ${ }^{384}$ Additionally, it said it was not provided with sufficient information to assess what portion of the Lafayette's reported catch was from non-Peruvian vessels. ${ }^{385}$ Furthermore, the Panel stated none of the submitting States had presented a convincing argument as to why Russia should be denied a share of the TAC. This was particularly anomalous when parties who may have entered the fishery after the Convention was negotiated were accorded potential windfall allocations. ${ }^{386}$ Russia was thus subject to unjustified discrimination. ${ }^{387}$

The Panel did not agree with Russia on the other aspects of its objection. It found that CMM 1.01 was compatible with the SPRFMO Convention and other law of the sea instruments. ${ }^{388}$ Moreover, it found Russia's alternate measures were not equivalent in effect to the decision it was objecting to. ${ }^{389}$ Russia had promised not to exceed the TAC. ${ }^{390}$ However, accommodating Russia within the TAC would have affected the allocations of other parties, meaning its measures lacked equivalence with CM 1.01. ${ }^{391}$ The Panel therefore recommended its own alternative measure. This sought to "avoid any inconsistency not only with the [TAC] but also with the allocations to other members and [co-operating non-contracting parties]". ${ }^{392}$ This measure allowed Russia to fish for jack mackerel, but only if SPRFMO confirmed the TAC of 360,000 tonnes would likely not be met in 2013. It also required Russia to stop fishing once SPRMFO reported that the TAC has been reached. ${ }^{393}$

\footnotetext{
${ }^{382}$ Review Panel, above n 310, at [100].

${ }^{383}$ At [100].

${ }^{384}$ At [91].

${ }^{385}$ At [91].

386 At [92].

${ }^{387}$ At [93].

${ }^{388}$ At [100].

${ }^{389}$ At [100].

${ }^{390}$ At [97].

${ }^{391}$ At 23.

392 At [99].

${ }^{393}$ At [100].
} 
Just over one month after the Panel reported its findings, SPRFMO announced that Russia had "confirmed its commitment to follow the recommendations made by the Panel". 394 Consequently, in accordance with Annex II of the SPRFMO Convention, the recommended alternative measures were now binding on Russia in substitution for CMM 1.01. ${ }^{395}$ The Panel process therefore successfully resolved this objection dispute.

\section{Evaluation of SPRFMO in Light of the Russia Dispute}

In his address to the Review Panel SPRFMO's Chairperson said it was "very important" that the Convention get "off to a good start". ${ }^{396}$ This was both in order to unify the SPRFMO member States "in support of the objective of the Convention" and to encourage others to join. ${ }^{397}$ Arguably the objection process did just that. Moreover, it demonstrated that a complex objection procedure can operate to successfully resolve a dispute as well as promote effective decision-making.

Firstly, the successful conclusion of the Panel process and Russia's commitment to follow the Panel's recommended alternative sets an important precedent. This is not only as an important affirmation of the Convention's objection procedure, but also as a step forward in cementing a rules based order for the South Pacific fisheries. Furthermore, the Panel process can also be seen as a positive step forward for transparent and timely decisionmaking. The Panel was able to successfully operate to a well-defined and tight timeframe. Indeed, it was deliberately drafted to achieve this, thereby avoiding drawn-out disputes that have undermined the decision-making efficacy of other RFMOs. ${ }^{398}$ The Panel process also resulted in the publicising of detailed member positions on the objection as well as a wealth of material on SPRFMO's operations. ${ }^{399}$ This has shed greater light into the organisation and into its decision-making.

The objection and Panel process has not been entirely positive. The process would have been resource consuming and probably divisive for SPRFMO and its members, as well as creating uncertainty around the finality and integrity of its decisions. Fortunately, the

\footnotetext{
394 South Pacific Regional Fisheries Management Organisation "Russian Federation Accepts Recommendations" South Pacific Regional Fisheries Management Organisation (7 August 2013) < www.sprmfo.int>.

${ }^{395}$ SPRFMO Convention, annex II para 10(b); and SPRFMO 2013 Annual Report (SPRFMO, 2014) at 2.

${ }^{396}$ Mansfield, above n 16, at 1.

${ }^{397}$ At 1.

${ }^{398}$ At 1.

${ }^{399}$ See SPRFMO "Supporting Material to the Information Paper for the Review Panel" (SPRFMO, June 2013).
} 
Panel's alternative measures sought both to minimise the likelihood of the TAC being exceeded and another participant's allocation being effectively re-allocated to Russia. In this instance, any negative sentiment regarding any reallocation should have been tempered by the finding that Russia was unjustifiably discriminated against by CMM 1.01. Fortuitously, the concerns expressed by New Zealand to the Panel did not come to pass. It appears that the 2013 TAC was not exceeded, with Russia not reporting any fishing for jack mackerel in 2013. ${ }^{400}$

It is difficult to see how the Panel could have come up with a different solution to the catch allocation conundrum it faced. A more restrictive equivalent measure would have effectively denied Russia any share of the TAC. Conversely, a more generous alternative measure would have had to trade-off either a larger TAC or a re-allocation of catch quota within the TAC. Either way decision acceptability or conservation-effect would have been undermined. Logically, it must therefore have reached the right conclusion on this matter. Additionally, this will likely set a precedent for how States are to set alternative measures when they dispute a catch allocation. Furthermore, it seems unlikely that a scientific report would have materially assisted the Panel in this particular dispute. Whilst the Panel said it was not supplied with sufficient information to determine the source of the Lafayette's nonPeruvian catch, the issues around the accuracy of the data appeared to be more political than scientific.

From a policy perspective, the substantive decision of the Panel was also arguably the right one. At the hearing, Russia was described by the Chairperson of the Commission as: ${ }^{401}$

a major State with a significant historical connection to fishing for jack mackerel in the Pacific as well as more recent activity in the fishery ... It actively participated from the beginning in the Consultations that resulted in the adoption of the Convention

Whilst the situation with Russia's reported data was undesirable, a zero allocation to a major participant in SPRFMO, without that State's consent, had the potential to damage the future effectiveness of the organisation. Indeed, the failure to account for Russia's position suggests the decision-making criteria was flawed. Game theory suggests that for RFMO players to behave cooperatively, "they need to be assured now and in the future of

\footnotetext{
${ }^{400}$ SPRFMO "Data Submitted to the SPRFMO Secretariat: $5^{\text {th }}$ March 2014" (March 2014) SPRFMO $<$ www.sprfmo.int> at 8 .

${ }^{401}$ Mansfield, above n 16, at 7.
} 
an economic return from cooperation at least as great as it would by acting competitively". ${ }^{402}$ In particular, "all must see the allocations as equitable". ${ }^{403}$ An allocation of zero to a state with a genuine interest in the fishery arguably fails both these conditions. If a member believes an allocation is unfair, then it might leave that organisation or decide not to constructively participate in its processes.

If SPRFMO is to be effective in the long-term it needs a wide participation and the good will and co-operation of those participants. ${ }^{404} \mathrm{~A}$ finding entirely against Russia would have possibly undermined these pre-conditions, blunting the ability of SPRFMO achieve its objectives from the start. On one hand the chances of it leaving would have been small. Jack mackerel is a straddling stock. Therefore as a signatory to the FSA, Russia would still have to co-operate with SPRFMO's conservation measures. ${ }^{405}$ Leaving SPRFMO would have been unlikely to improve Russia's position. However, on the other hand, Russia may have chosen to pursue the dispute further. ${ }^{406}$ By adding further cost and uncertainty to the process, this may have discredited the objection procedure form the start. Ultimately, Russia might become inclined to act as an obstructive force within SPFMO, if it felt it had little to gain from constructive cooperation. The combined effect of these responses may have been to discourage other nations from joining the organisation.

The possible response of Russia remaining within SPRFMO as a disruptive force, instead of leaving, might have been a potential example of an anomaly in the FSA. Örebech et al. note that the FSA provides that a State can satisfy its duty of cooperation by joining an RFMO. ${ }^{407}$ Conversely, States that are not members of the RFMO must agree to apply the conservation and management measures of the relevant RFMO. As only participants within RFMOs are entitled to object to CMMs, Article 8 of the FSA thus, arguably, imposes a higher burden on non-participants than participants. The policy behind this may have been to induce states to become members of RFMOs. In this scenario, it would indeed operate to keep Russia within SPRFMO. Whether that would have been a positive for the Organisation is open to question.

\footnotetext{
402 Anderson et al, above $\mathrm{n}$ 9, at 12-13.

${ }^{403}$ At 13 .

${ }^{404}$ At $\mathrm{X}$ and 1.

${ }^{405}$ Fish Stocks Agreement, art 8(3).

${ }^{406}$ See SPRFMO Convention, annex II 10(b); Deuchars, above n 311, at 21.

${ }^{407}$ Peter Örebech et al,. The 1995 United Nations Straddling and Highly Migratory Fish Stocks Agreement (1998) 13 INT'L J Marine and Coastal 119 at 125 as cited in Schiffman Marine Conservation, above n 30, at 192 .
} 
Overall, the Panel's decision can be seen as an important corrective measure. Russia's interests in the fishery were accommodated and the conservation effect of the disputed decision was maintained. It sends a signal that States can successfully challenge substantive decisions if they have genuine grounds for doing so. In an RFMO where substantive decisions can be taken without consensus, the importance of this should not be understated in terms of encouraging further membership of SPRFMO. ${ }^{408}$ Indeed, in this case, the concerns of the minority were essentially overridden by the majority. Moreover, the decision also shows that the Convention's novel objection procedures ultimately worked to resolve a major dispute. Altogether, these outcomes illustrate the merits of submitting objections to a form of collective review.

Finally, as SPRFMO moves past this dispute, an important test for the objection procedure will be how often it is invoked. For it to be effective it will have to be used judiciously by SPRFMO members. ${ }^{409}$ However, only time will tell whether member states end up abusing the objection procedures to stymy the work of SPRFMO.

\section{Synthesis: Is SPRFMO a Model for RFMO Decision-Making?}

The outcomes of the Russia Review Panel arguably bode well for SPRFMO and its 'innovative' decision-making processes. The dispute has apparently been resolved, with the objecting State obtaining the main outcome that it was seeking whilst also agreeing to not undermine the conservation management measures put in place. Simply put, the objection mechanism worked. When this viewed along with SPRFMO's performance against the framework developed in this paper, it forms a compelling model for RFMO decision-making.

SPRFMO is part of a trend of RFMOs using increasingly complex decision-adoption and objection procedures in order to ensure State behaviour that is consistent with the relevant conservation regime and the law of the sea. ${ }^{410}$ This includes the use of review panels, reasoned objections, interim measures to protect fish stock sustainability and limited grounds for review. However, SPRFMO takes RFMO design a step further and comprehensively applies all these elements to every objection, greatly reducing the scope for abuse. The Russia objection case study illustrates that this objection process has worked exactly as intended. Furthermore, its decision-adoption process addresses the problems

\footnotetext{
${ }^{408}$ Schiffman Marine Conservation, above n 30, at 215.

${ }^{409}$ Mossop, above n 99, at 338; and Schiffman Marine Conservation, above n 30, at 296.

${ }^{410}$ Schiffman "The South Pacific Regional Fisheries Management Organization", above n 16, at 212; McDorman, above n 38, at [16]; and Meltzer, above n 14, at 194.
} 
associated with strict consensus-based decision-making. SPRFMO thus offers clear solutions to the problems associated with RFMO decision-making processes.

McDorman reminds us that it is calculated risk as to whether complex procedures will improve effectiveness, or indeed be an improvement on existing models. ${ }^{411}$ They potentially jeopardise timeliness and decision acceptability. ${ }^{412}$ However, considering historically poor performance of RFMOs, new approaches are arguably worth the risk. Indeed, States that are serious about creating more robust and effective decision-making processes should take a calculated risk and give serious consideration to implementing SPRFMO's approach. Its combination of best practice elements will not prevent all disputes, nor will it ensure its members agree on effective conservation and management measures. No decision-making can guarantee this. ${ }^{413}$ However, its rules do ensure is that no one member can hold up its process or lawfully undermine the conservation and management regime. Moreover, every objection is subject to robust scrutiny. Altogether, these procedures do their utmost to force "discipline consistent with the objectives of the convention". ${ }^{414}$ In an environment where the content and enforcement of decisions ultimately comes down to the will of sovereign States, this is arguably the best that can be hoped for from a decision-making process. ${ }^{415}$

In all likelihood, accepting SPRFMO's processes will probably be too great an infringement on State sovereignty for some States. Indeed, McDorman has argued the differences between every RFMO mean "there is no one model process for decisionmaking that can be held out as the most appropriate for RFMOs". ${ }^{416}$ Regardless of whether the SPRFMO model works for a particular RFMO, this paper has outlined several alternative options that can help RFMO processes strike a better balance between Sovereignty and decision-making efficacy. Moreover, Schiffman contends that: ${ }^{417}$

as existing marine conservation regimes struggle to meet present needs, and newer regimes are developed in the future, exemptive mechanisms must evolve to help guarantee they do not contribute to the decline of our oceans. At a minimum, states

\footnotetext{
${ }^{411}$ McDorman, above n 38, at [13].

412 At [13].

413 Joyner, above n 144, at 127; and Meltzer, above n 14, at [8.1].

${ }^{414}$ Ceo et al, above n 142, at 90.

415 Joyner, above n 144, at 127.

416 McDorman, above n 38, at [40].

417 Schiffman Marine Conservation, above n at 199
} 
must explore ways to refine them to help ensure that they do not undermine conservation objectives

Reforms as simple as appointing independent conciliators and requiring to States to provide reasons for an objection can help promote consensus and reduce the abuse of objection procedures. Therefore, there should be few excuses for modest change.

There will be practical difficulties when it comes to introducing international best practice into the decision-making processes of all RFMOs. Indeed, McDorman observes:

decision-making procedures for RFMOs, (including the manner for adopting decisions, objection procedures, dispute settlement and the infusion of science and other factors in decision-making) are almost always found within the constitutive treaty establishing the RFMO. Thus, any change to decision-making procedures almost always requires amendment of the RFMO constitutive treaty and each treaty has its own amendment process. ${ }^{418}$

Moreover, the OECD notes that "gaining support for change within RFMOs is difficult when diverse national agendas and economic priorities are at stake". ${ }^{419}$ Comprehensively introducing effective decision-making processes will therefore not be easy. However, the fact that a diverse array of countries were able to build a best practice regime for the South Pacific shows it is possible for States to meet this challenge. Additionally, the new NAFO agreement illustrates that a conflict-ridden RFMO can rebuild trust and co-operation and agree to introduce a process that will promote more effective decisions. ${ }^{420}$ Furthermore, both SPRFMO and the NAFO reforms demonstrate that States do respond where the state of fish stocks reach crisis-like conditions. ${ }^{421}$ Whilst it is unfortunate that action comes so late in the picture, the current state of fish-stocks is arguably conducive to States reexamining other RFMOs and attempting more meaningful reforms. They will have the benefit of SPRFMO's best practice example if they chose to do so.

\section{Conclusion}

"The ability to make management decisions is the defining feature and central task of RFMOs." ${ }^{22}$ It is therefore unfortunate that "the lack of a resilient and efficient decision-

${ }^{418}$ McDorman, above $n$ 38, at [8].

${ }^{419}$ Cox et al., above $n 189$, at 20.

420 At 103 .

${ }^{421}$ Cox et al, above n 189, at ch 5; and Schiffman Marine Conservation, above n 30, at 62-63.

${ }^{422}$ Meltzer, above n 14, at 187 
making processes" have "often compromised the effectiveness of RFMOs and has contributed to the overexploitation of target and non target stocks". ${ }^{423}$ The challenge is to find solutions that respect "State sovereignty while minimizing the scope of States to hinder the adoption and effective implementation of conservation and management measures that science and the state of stocks require". ${ }^{424}$

SPRFMO's decision-making structure has arguably met this challenge. Whilst this model may not work for all RFMOs, it certainly provides a framework from which others can seek to improve their own decision-making processes. Its decision-making approach has sought to avoid the fundamental issues identified in this paper. These are the problems associated with consensus-based decision-making and easily abused objection procedures. Its decision-adoption process seeks to build consensus whilst recognising that it may not be possible in every instance. Its objection procedure also acknowledges that States may have legitimate reasons to object to a decision, but aims to limit frivolous use as well as limit the conservation impact of any objections. The Russia objection has illustrated why this process is necessary, and that objection procedures can be designed not only avoid negative conservation impacts, but also to promote, rather than undermine, better decisionmaking outcomes.

Altogether, SPRFMO's decision-making approach offers hope that it will succeed where others have failed, with principles and an objection process that should keep the organisation on track. However, whether this hope is realised will ultimately depend on the political will of its members. Indeed, political will is also critical to whether States choose to push for further reform in other RFMOs, reform that cannot come soon enough for high seas fisheries.

${ }^{423}$ Meltzer, above n 14, at 187.

${ }^{424}$ McDorman, above n 38, at [5]. 


\section{Bibliography}

\section{A Conventions}

Agreement for the Establishment of the Indian Ocean Tuna Commission 1927 UNTS 329 (signed 25 November 1993, entered into force March 27 1996)

Agreement for the Establishment of a General Fisheries Council for the Mediterranean as amended by the General Fisheries Council for the Mediterranean 2275 UNTS 157 (6 November 1997),

Agreement for the Implementation of the Provisions of the United Nations Convention on the Law of the Sea of 10 December 1982 relating to the Conservation and Management of Straddling Fish Stocks and Highly Migratory Fish Stocks 2167 UNTS 3 (opened for signature 4 December 1995, entered into force 11 December 2001).

Amendment to the Convention on Future Multilateral Cooperation in the Northwest Atlantic Fisheries (adopted 28 September 2008, not yet in force).

Convention on the Conservation and Management of High Seas Fishery Resources in the South Pacific Ocean [2012] ATS 28 (opened for signature 1 February 2010, entered into force 24 August 2012).

Convention on the Conservation of Antarctic Marine Living Resources 1329 UNTS 47 (opened for signature 20 May 1980, entered into force 7 April 1982).

Convention for the Conservation of Anadromous Stocks in the North Pacific Ocean (Signed 11 February 1992, entered into force 16 February 1993).

Convention for the Conservation of Salmon in the North Atlantic Ocean 1338 UNTS 34 (signed 2 March 1982, entered into force 1 October 1983).

Convention for the Conservation of Southern Bluefin Tuna 1819 UNTS 360 (opened for signature 10 May 1993, entered into force 20 May 1994).

Convention for the Establishment of the Inter-American Tropical Tuna Commission 80 UNTS 3 (signed 31 May 1947, entered into force March 3 1950). 
Convention for the Strengthening of the Inter-American Tropical Tuna Commission Established by the 1949 Convention between the United States of America and the Republic of Costa Rica available at http://www.iattc.org/PDFFiles2/Antigua_Convention_Jun_2003.pdf(opened for signature November 14 2003, entered into force August 27 2007).

Convention on the Conservation and Management of Pollock Resources in the Bering Sea 34 ILM 67 (opened for signature 16 June 1994, entered into force 8 December 1995).

Convention on the Conservation and Management of Highly Migratory Fish Stocks in the Western and Central Pacific Ocean [WCPFC Convention] 2275 UNTS 43 (signed 5 September 2000, entered into force 19 June 2004).

Convention on Fishing and Conservation of the Living Resources in the Baltic Sea and the Belts 1090 UNTS 93 (signed 13 September 1973, entered into force 28 July 1974).

Convention on Future Multilateral Co-operation in the Northwest Atlantic Fisheries 1135 UNTS 369 (signed 24 October 1978, entered into force January 1 1979).

Convention on Future Multilateral Co-operation in North-East Atlantic Fisheries 1285 UNTS 130 (signed 18 November 1980, entered into force 17 March 1982).

Convention between the United States of America and Canada for the Preservation of the Halibut Fishery of the Northern Pacific Ocean and Bering Sea 222 UNTS 77 (signed 2 March 1953, entered into force 28 October 1953).

International Convention for the Conservation of Atlantic Tunas 673 UNTS 63 (signed 14 May 1966, entered into force 21 March 1966).

Southern Indian Ocean Fisheries Agreement available at http://www.fao.org/fileadmin/user_upload/legal/docs/2_035t-e.pdf(opened for signature 7 July 2006, entered into forced 21 June 2012).

Treaty Between the Government of Canada and the Government of the United States of America Concerning Pacific Salmon 1469 UNTS 358 (signed 28 January 1985, entered into force 18 March 1985). 
United Nations Convention on the Law of the Sea 1833 UNTS 3 (opened for signature 10 December 1982, entered into force 16 November 1994).

Vienna Convention on the Law of Treaties 1155 UNTS 157 (opened for signature 23 May 1969, entered into force 27 January 1980).

\section{B Review Panel Materials}

Review Panel Established under the Convention on the Conservation and Management of High Seas Fisheries Resources in the South Pacific Ocean (Fisheries Management Dispute) PCA (5 July 2013).

Bill Mansfield Presentation by the Chairperson of the SPRFMO Commission to the Review Panel (South Pacific Regional Fisheries Management Organisation, July 2013).

Ministerio de Economia, Fomento Y Turismo Chile "Written Memorandum of the State of Chile" (21 June, 2013) South Pacific Regional Fisheries Management Organisation $<$ www.southpacificrfmo.org>

New Zealand Ministry of Foreign Affairs and Trade "Memorandum of New Zealand to the Review Panel" (21 June 2013) South Pacific Regional Fisheries Management Organisation $<$ www.southpacificrfmo.org>

Russian Federation Federal Agency for Fisheries "Letter of Objection to Conservation and Management Measure 1.01" (19 April 2013) South Pacific Regional Fisheries Management Organisation <www.southpacificrfmo.org $>$

Russian Federation Federal Agency for Fisheries "Submissions to the Review Panel" (14 June 2013) South Pacific Regional Fisheries Management Organisation $<$ www.southpacificrfmo.org $>$

South Pacific Regional Fisheries Management Organisation "Establishment of Review Panel" (21 May 2013) South Pacific Regional Fisheries Management Organisation $<$ www.southpacificrfmo.org $>$

South Pacific Regional Fisheries Management Organisation Information Paper for the Review Panel (South Pacific Regional Fisheries Management Organisation, June 2013). 
South Pacific Regional Fisheries Management Organisation Supporting Material to the Information Paper for the Review Panel (South Pacific Regional Fisheries Management Organisation, June 2013).

South Pacific Regional Fisheries Management Organisation "Russian Federation Accepts Recommendations" (7 August 2013 South Pacific Regional Fisheries Management Organisation) $<$ www.southpacificrfmo.org $>$.

\section{Books and Monographs}

Scott Barrett Environment and Statecraft: The Strategy of Environmental Treaty-Making (Oxford, Oxford University Press, 2003).

Patricia Birnie, Alan Boyle and Catherine Redgwell International Law \& the Environment (Oxford University Press, Oxford, 2009).

Robin Churchill and Vaughan Lowe The Law of the Sea $\left(3^{\text {rd }}\right.$ ed., Juris Publishing, Manchester, 1999).

Alex G. Oude Elferink and Erik J. Molenaar (ed.) The International Legal Regime of Areas Beyond National Jurisdiction: Current and Future Developments (Martinus Nijhoff, Boston, 2010).

Maria Gavouneli Functional Jurisdiction in the Law of the Sea (Martinus Hijhoff, Boston, 2007).

Tore Henriksen, Geir Hønneland and Are Sydnes Law and Politics in Ocean Governance: The UN Fish Stocks Agreement and Regional Fisheries Management Regimes (Leiden, Martinus Nijhoff Publishers, 2006).

Christopher C. Joyner, Governing the Frozen Commons: The Antarctic Regime and Environmental Decision-Making (University of South Carolina Press, Columbia, 1998).

Evelyne Meltzer "The Quest for Sustainable International Fisheries: Regional Efforts to Implement the 1995 United Nations Fish Stocks Agreement" (National Research Council of Canada, 2009). 
Daniela Diz Pereira Pinto Fisheries Management in Areas Beyond National Jurisdiction: The Impact of Ecosystem Based Law-Making (Martinus Nijhoff, Boston, 2013).

Donald R Rothwell and Tim Stephens The International Law of the Sea (Hart Publishing, Portland, 2010).

Dawn A. Russell and David L.Vanderswagg (ed.) Recasting Transboundary Fisheries Management Arrangements in Light of Sustainability Principles (Martinus Nijhoff Publishers, Leiden, 2010).

Howard S Schiffman Marine Conservation Agreements: the Law and Policy of Reservations and Vetoes (Martinus Nijhoff Publishers, Boston, 2008).

Olav Schram Stokke The Effectiveness of CCAMLR in Governing the Antarctic: The Effectiveness and Legitimacy of the Antarctic Treaty System (Cambridge, Cambridge University Press, 1996).

Judith Swan Decision-Making in Regional Fisheries Bodies or Arrangements: The Evolving Role of RFBS and International Agreement on Decision-Making Processes (FAO, Fisheries Circular No. 995, 2004)

Yoshinobu Takei Filling Regulatory Gaps in High Seas Fisheries (Martinus Nijhoff Publishers, Boston, 2013).

Yoshifumi Tanaka The International Law of the Sea (Cambridge University Press, Cambridge, 2012).

Robin Warner Protecting the Oceans beyond National Jurisdiction: Strengthening the International Law Framework (Martinus Nijhoff Publishers, Boston, 2009).

\section{Journal Articles}

Kristen E Boon "Overfishing of Bluefin Tuna: Incentivising Inclusive Solutions" (2013) 52 U Louisville L Rev 1.

Elise Anne Clark "Strengthening Regional Fisheries Management - An Analysis of the Duty to Cooperate" (2011) 9 NZJPIL 223. 
Sarika Cullis-Suzuki and Daniel Pauly "Failing the high seas: A global evaluation of regional fisheries management organizations" (2010) 34 Marine Policy 1036.

The Economist "Governing the Oceans: The Tragedy of the High Seas" (2014) 410 The Economist 10.

Joanna Mossop "Law of the Sea and Fisheries" (2009) 7 NZYIL 336.

Howard S. Schiffman "The Evolution of Fisheries Conservation and Management: A Look at the New South Pacific Regional Fisheries Management Organisation in Law and Policy" (2011) 28:2 T M Cooley L Rev 181.

Howard S. Schiffman "The South Pacific Regional Fisheries Management Organization (SPRFMO): an improved model of decision-making for fisheries conservation?" (2013) 3 J Environ Stu Sci 209.

Are K. Sydnes "Regional Fishery Organizations: How and Why Organizational Diversity Matters” (2001) 32 Ocean Dev \& Intl'1 L 349.

\section{E Papers and Reports}

David Anderson, Michael W. Lodge, Terje Løbach, Gordon Munro, Keith Sainsbury, Anna Willock Recommended Best Practices for Regional Fisheries Management Organizations: Report of an Independent Panel to Develop a Model for Improved Governance by Regional Fisheries Management Organisations (Chatham House, 2007).

Marika Ceo, Sarah Fagnani, Judith Swan, Kumiko Tamada and Hiromoto Watanabe Performance Reviews by Regional Fishery Bodies: Introduction, Summaries, Synthesis and Best Practices (Food and Agriculture Organization of the United Nations, FAO Fisheries and Aquaculture Circular No. 1072, 2012).

Sarika Cullis-Suzuki and Daniel Pauly Evaluating Global Fisheries Management Organizations: Methodology and Scoring (University of British Columbia Fisheries Centre, Working Paper 2009-12, 2009).

Anthony Cox, Leonie Renwrantz and Ingrid Kelling Strengthening Regional Fisheries Management Organisations (Organisation for Economic Co-Operation and Development, 2009). 
Jorge Csirke, Serge Garcia, Richard Grainger, Jean-Jacques Maguire and Michael Sissenwine The State of World Highly Migratory, Straddling and Other High Seas Fishery Resources and Associated Species (United Nations Food and Agriculture Organisation, FAO Fisheries Technical Paper No 496, 2006).

Robert Deuchars "Governmentality and Risk: Managing 'Ocean Space”" (LLM Research Paper, Victoria University of Wellington 2013).

Food and Agriculture Organization of the United Nations Fisheries and Aquaculture Department State of World Fisheries and Aquaculture 2008 (FAO, 2009).

Food and Agriculture Organization of the United Nations Fisheries and Aquaculture Department International Plan of Action to Prevent, Deter and Eliminate Illegal, Unreported and Unregulated Fishing (Food and Agriculture Organization of the United Nations, 2001).

Global Ocean Commission Improving Accountability and Performance in International Fisheries Management (Global Ocean Commission, November 2013).

Global Ocean Commission Modernising Ocean Governance (Global Ocean Commission, November 2013).

Michael Lodge Managing International Fisheries: Improving Fisheries Governance by Strengthening Regional Fisheries Management Organisations (Chatham House, March 2007).

Michael Lodge Report and Documentation of the International Workshop on Factors Contributing to Unsustainability and Overexploitation of Fisheries (FAO, Fisheries Report No. 672, 2002).

Ted L. McDorman "Decision-Making Processes of Regional Fisheries Management Organizations (RFMOs) (paper presented to the Conference on Global High Seas Fisheries and the United Nations Fish Stocks Agreement, St Johns, Newfoundland, May 2005).

Pew Environment Group High Seas Management Gets Low Marks: A Summary of a New Scientific Analysis (Pew Environment Group, May 2010). 
Report of the Review Conference on the Agreement for the Implementation of the United Nations Convention on the Law of the Sea of 10 December 1982 relating to the Conservation and Management of Straddling Fish Stocks and High Migratory Fish Stocks A/CONF.210/2006/16 (2006).

Secretary-General of the United Nations Oceans and Law of the Sea: Report of the Secretary General A/69/71 (2014).

Making the Fish Stocks Agreement Work (United Nations Department of Public Information, DPI/2556 F, May 2010).

\section{F Online Materials}

Mar Cabra and Mort Rosenblum "In Mackerels Plunder Hints of Epic Fish Collapse" New York Times (online ed, New York, 25 January 2012).

Mar Cabra and Mort Rosenblum "Where have all the fish gone?" The Sydney Morning Herald (online ed, Sydney, 30 January 2012).

Fisheries Department of the European Commission "Regional Fisheries Management Organisations" (June 2014) European Commission <www.ec.europa.eu>.

Fisheries and Aquaculture Department "Governance of High Seas Fisheries" (2014) Food and Agriculture Organization of the United Nations $<$ www.fao.org $>$.

Oxford University "Oxford Dictionaries: Definition of Effectiveness" (2014) Oxford Dictionaries $<$ www.oxfordictionaires.com $>$.

South Pacific Regional Fisheries Management Organisation “2013 Annual Report” South Pacific Regional Fisheries Management Organisation (2014) < Www.southpacificrfmo.org>.

South Pacific Regional Fisheries Management Organisation "Data Submitted to the SPRFMO Secretariat: $5^{\text {th }}$ March 2014" (5 March 2014) South Pacific Regional Fisheries Management Organisation <www.southpacificrfmo.org $>$. 